\title{
MULTIMODAL EVALUATION OF ESOPHAGEAL EPITHELIAL RESPONSE IN GASTROESOPHAGEAL REFLUX DISEASE
}

\author{
Ph.D. Thesis
}

\section{Dorottya Laczkó M.D.}

Supervisors:

Viktória Venglovecz Ph.D., Department of Pharmacology and Pharmacotherapy, University of Szeged

András Rosztóczy M.D. Ph.D., First Department of Medicine, University of Szeged

Department of Pharmacology and Pharmacotherapy,

First Department of Medicine,

University of Szeged, Szeged

Hungary

2016 


\section{TABLE OF CONTENTS}

1. LIST OF ABBREVIATIONS - 4 -

2. LIST OF FULL PAPERS CITED IN THE THESIS - 5 -

3. LIST OF FULL PAPERS NOT RELATED TO THE THESIS - 5 -

4. SUMMARY - 6 -

5. INTRODUCTION - 8 -

5.1. Definition and epidemiology of GERD -8 -

5.2. Classification and clinical manifestation of GERD - 8 -

5.2.1. NERD - 9 -

5.2.2. ERD - 9 -

5.2.3. $\mathrm{BE}-9$ -

5.3. Pathogenesis of GERD - 9 -

5.3.1. The role of ion transporters in the pathogenesis of GERD - 10 -

5.3.2. The role of autophagy in the pathogenesis of GERD and BE - 11 -

5.3.3. Modeling the pathogenesis of GERD - 12 -

6. AIMS - 13 -

7. MATERIALS AND METHODS 14 -

7.1. Cell lines -14 -

7.2. 3-dimensional organotypic culture (3D OTC) - 14 -

7.3. Immune cells and cytokine treatment -15 -

7.4. Patients - 16 -

7.5. Chemicals and solutions -16 -

7.6. Measurement of $\mathrm{pH}_{\mathrm{i}}$ and $\left[\mathrm{Ca}^{2+}\right]_{\mathrm{i}}$ with microfluorimetry - 17 -

7.7. Determination of buffering capacity and base efflux - 18 -

7.8. Measurement of the activity of NHE, NBC and CBE - 18 -

7.9. Bile acid treatments 19 -

7.10. RNA isolation, reverse transcription and quantitative real-time PCR - 19 -

7.11. Western Blot analysis -20 -

7.12. Immunohistochemistry -20 -

7.13. TUNEL assay -21 -

7.14. Flow cytometry analysis - 21 - 
7.15. Statistical analysis 21 -

8. RESULTS 22 -

8.1. Role of ion transporters in the bile acid-induced esophageal injury - 22 -

8.1.1. The main $\mathrm{pH}_{\mathrm{i}}$ regulatory mechanisms in human EECs $\quad 22$ -

8.1.2. Bile acids induces $\mathrm{Ca}^{2+}$ release via activation of $\mathrm{IP}_{3}$-mediated pathway - 26 -

8.1.3. Acute effects of bile acids on the activity of ion transporters in EECs $\quad 28$ -

8.1.4. Chronic exposure of EECs to bile acids - 30 -

8.2. Role of autophagy in the pathogenesis of GERD and BE - 33 -

8.3. Modeling esophagitis using 3D organotypic culture system - 37 -

8.3.1. The organotypic culture environment sustains immune cells and permits their normal activation when stimulated by cytokines $\quad$ - 37 -

8.3.2. Inflammatory OTC environment induces changes in epithelial morphology - 40 -

8.3.3. The pro-inflammatory environment modeled with the OTC culture system alters cell

proliferation and cell death in the epithelium $\quad$ - 41 -

9. DISCUSSION $\quad 43$ -

10. CONCLUSIONS AND NEW RESULTS 49 -

11. ACKNOWLEDGEMENTS 50 -

12. REFERENCES - 51 - 


\section{LIST OF ABBREVIATIONS}

2D: 2-dimensional

3D: 3-dimensional

7AAD: 7-amino actinomycin D

AV: autophagic vesicle

BAC: bile acid cocktail

$\mathrm{BE}$ : Barrett's esophagus

BCECF-AM: 2',7'-bis-(2-carboxyethyl)-5-(and-6)-carboxyfluorescein, acetoxymethyl ester $\left[\mathrm{Ca}^{2+}\right]_{\mathrm{i}}$ : intracellular $\mathrm{Ca}^{2+}$ concentration

$\mathrm{CBE}: \mathrm{Cl}^{-} / \mathrm{HCO}_{3}{ }^{-}$exchanger

CQ: chloroquine

DCF: 2',7'-dichlorodihydrofluorescein diacetate

EAC: esophageal adenocarcinoma

EECs: esophageal epithelial cells

GERD: gastroesophageal reflux disease

IFN- $\gamma$ : interferon- $\gamma$

IHC: immunohistochemistry

IRF-1: interferon regulatory factor-1

IL: interleukin

$\mathrm{pH}_{\mathrm{i}}$ : intracellular $\mathrm{pH}$

NHE: $\mathrm{Na}^{+} / \mathrm{H}^{+}$exchanger

NBC: $\mathrm{Na}^{+} / \mathrm{HCO}_{3}{ }^{-}$cotransporter

OTC: organotypic culture

PBMC: peripheral blood mononuclear cell

ROS: reactive oxygen species

SE: squamous epithelium 


\section{LIST OF FULL PAPERS CITED IN THE THESIS}

I. Dorottya Laczkó, András Rosztóczy, Klaudia Birkás, Máté Katona, Zoltán Rakonczay Jr., László Tiszlavicz, Richárd Róka, Tibor Wittmann, Péter Hegyi, Viktória Venglovecz. Role of ion transporters in the bile acid-induced esophageal injury. American Journal of Physiology-Gastrointestinal and Liver Physiology 2016 Jul 1;311(1):G16-31. IF (2015): 3.798

II. Jianping Kong*, Kelly A. Whelan*, Dorottya Laczkó, Brendan Dang, Angeliz Caro Monroig, Ali Soroush, John Falcone, Ravi K. Amaravadi, Anil K. Rustgi, Gregory G. Ginsberg, Gary W. Falk, Hiroshi Nakagawa, John P. Lynch. Autophagy levels are elevated in Barrett's esophagus and promote cell survival from acid and oxidative stress. Molecular Carcinogenesis 2016 Nov;55(11):1526-1541. IF (2015): $\mathbf{4 . 8 0 8 ~ ( * t h e s e ~ a u t h o r s ~ c o n t r i b u t e d ~ e q u a l l y ) ~}$

III. Dorottya Laczkó, Fang Wang, F. Bradley Johnson, Nirag Jhala, András Rosztóczy, Gregory G. Ginsberg, Gary W. Falk, Anil K. Rustgi, John P. Lynch: Modeling esophagitis using human 3D organotypic culture system. American Journal of Pathology (Under revision)

\section{LIST OF FULL PAPERS NOT RELATED TO THE THESIS}

IV. Andrea Szentesi, Emese Tóth, Emese Bálint, Júlia Fanczal, Tamara Madácsy, Dorottya Laczkó, Imre Ignáth, Anita Balázs, Petra Pallagi, József Maléth, Zoltán Rakonczay Jr, Balázs Kui, Dóra Illés, Katalin Márta, Alexandra Demcsák, Andrea Párniczky, Gabriella Pár, Szilárd Gódi, Dóra Mosztbacher, Ákos Szücs, Adrienn Halász, Ferenc Izbéki, Nelli Farkas, Péter Hegyi: Analysis of Research Activity in Gastroenterology: Pancreatitis is in Real Danger Plos One 2016 (Accepted for publication PONE-D-16-26557R1) IF (2015): 3.057

Number of full publications: 3 (1 first author)

Cumulative impact factor: $\mathbf{1 1 . 6 6 3}$ 


\section{SUMMARY}

Background \& Aims: In gastroesophageal reflux disease (GERD) gastric acid and bile reflux into the esophagus causing symptoms and/or complications. GERD is a significant condition of the gastrointestinal tract, affecting nearly $20 \%$ of the population of the Western countries. The refluxate can cause tissue injury and trigger an inflammatory response. GERD and the resulting subsequent inflammation are risk factors for the development of esophageal strictures, Barrett's esophagus (BE), and esophageal adenocarcinoma (EAC). Therefore, the investigation of the pathogenesis of GERD is of critical importance. The aims of our studies:

I. To investigate the role of ion transport mechanisms in the esophageal mucosal defense against bile acid-induced cellular injury, in Barrett's derived esophageal epithelial cells

II. Characterize the functional role of autophagy in a wide range of esophageal epithelial cell lines from normal squamous to Barrett's and adenocarcinoma cells

III. To modify the newly developed, innovative multicellular 3-dimensional (3D) organotypic culture system (OTC) to model inflammatory conditions observed in patients with reflux disease.

\section{Methods:}

I. In order to study ion transport mechanisms, non-dysplastic (CP-A) and dysplastic (CPD) human Barrett's derived cell lines were acutely exposed to bile acid cocktail (BAC) and the changes in intracellular $\mathrm{pH}\left(\mathrm{pH}_{\mathrm{i}}\right)$ and $\mathrm{Ca}^{2+}$ concentration $\left(\left[\mathrm{Ca}^{2+}\right]_{\mathrm{i}}\right)$ were measured by microfluorometry. mRNA and protein expression of ion transporters were investigated by qPCR, Western blot, and immunohistochemistry (IHC) in cell lines and human esophageal biopsy samples.

II. To demonstrate a functional role for autophagy, normal squamous (STR), Barrett's derived (CP-A and CP-D), and adenocarcinoma (OE19) cell lines were exposed to an acid pulse $(\mathrm{pH}=3.5)$ followed by incubation in the presence or absence of chloroquine (CQ), an autophagy inhibitor and the level of reactive oxygen species (ROS), autophagy level and cell survival were measured by flow cytometry. 
III. OTC system is a novel engineered 3D human tissue reconstruction in which human esophageal fibroblasts are embedded in a collagen matrix with human esophageal epithelial cells (EECs) seeded on top. To model esophagitis peripheral blood mononuclear cells (PBMCs) were included in the collagen matrix. After 15 days OTCs were harvested for histological analysis, RNA and protein isolation. Cultures were then screened for changes in epithelial morphology, cell proliferation and apoptosis.

\section{Results and Conclusions:}

I. We have identified the presence of a $\mathrm{Na}^{+} / \mathrm{H}^{+}$exchanger (NHE), $\mathrm{Na}^{+} / \mathrm{HCO}_{3}{ }^{-}$ cotransporter (NBC), and a $\mathrm{Cl}^{-}$-dependent $\mathrm{HCO}_{3}{ }^{-}$secretory mechanism in $\mathrm{CP}-\mathrm{A}$ and CP-D cell lines. Acutely administered BAC stimulated $\mathrm{HCO}_{3}{ }^{-}$secretion in both cell lines and the NHE activity in CP-D cells by an inositol triphosphate-dependent $\mathrm{Ca}^{2+}$ release. Chronic treatment of the cells increased the expression of ion transporters compared to non-treated cells. A similar expression pattern was observed in biopsy samples from BE compared with normal squamous epithelium (SE). We speculate that these adaptive processes of the metaplastic cells represent an important mucosal defense against the bile acid-induced epithelial injury.

II. Pharmacologic inhibition of autophagy by CQ following acid stress has increased the level of ROS in STR and CP-A cells and diminished cell survival in all cell lines. Our findings provide new evidences that autophagy may have an important contribution to the pathogenesis and progression of $\mathrm{BE}$.

III. Addition and activation of immune cells in the OTC system induced apoptosis as well as a regenerative response in the epithelial cells, as has been seen in human GERD pathology. These findings support the concept that OTC can be adapted to model inflammatory conditions in GERD and to understand better the pathophysiology of the disease.

In summary, in this Ph.D. thesis we tried to give a better insight into the cellular and molecular events in GERD. We believe that our studies may provide new possibilities to develop new strategies in the treatment of GERD and BE. 


\section{INTRODUCTION}

\subsection{Definition and epidemiology of GERD}

GERD is one of the most common disorder of the gastrointestinal system. It refers to a condition where the retrogate flow of gastric and duodenal content provokes symptoms and/or complications. (1, 2) According to population-based studies, GERD-related symptoms are extremely common in adults and they are sufficient to impair significantly the health-related quality of life. (3) Weekly occuring reflux-related symptoms are reported by nearly $20 \%$ of the population in developed Western countries. (4) Moreover their incidence and prevalence increases in such parts of the world where they were previously uncommon, particularly in South-East Asia and the Far East. $(1,5)$

\subsection{Classification and clinical manifestation of GERD}

GERD is divided into three phenotypic subcategories: non-erosive GERD (NERD), erosive GERD (ERD) and Barrett's esophagus (BE) based on the endoscopic evaluation of the esophagus. Although some authors considered GERD as a spectrum disease, which is caracterized by the gradual progression from the mildest non-erosiv form to the most severe stages (stricture, adenocarcinoma) data support better the more recent phenotypic subgroup theory of Fass, since a little if any transformation can be detected between them. (6)

GERD can be classified based on the presence or absence of reflux related typical or atipical symptoms according to the Montreal criteria as well. (7) In contrast to the instrumental (endoscopy + esophageal function testing) diagnosis this latter has the advantage of considering troublesome symptoms, although asymptomatic GERD patients (silent GERD) may not be recognized by this system. This is particularly important in BE where a significant proportion of the patients have not reflux related symptoms at all (8)

The typical GERD symtoms are heartburn and/or acid regurgitation. In addtition, GERD can present with other less typical manifestations like cardiac chest pain, chronic cough, ear, nose and throat symptoms. Interestingly, NERD patients do not neccesserely have excesscive amount 
of acid regurgitation (9) and the classical anatomical alterations like hiatal hernia is less prevelant. (10)

\subsubsection{NERD}

Nearly $60 \%$ of GERD patients fall into this category. NERD refers to a condition where pathologic reflux is present in the absence of endoscopically visible mucosal injury. However, ultrastructural abnormalities are demonstrated at this stage of the disease as well evidenced by the dilatation of intercellular spaces which can give a possible explantion for the development of the symptoms. (11)

\subsubsection{ERD}

$35 \%$ of GERD are presented as ERD. These patients have macroscopically visible mucosal injury during upper endoscopy. Although most patients have non progressive mild to moderate forms a minority may progress and end up in severe complications such as esophageal perforation, bleeding or esophageal stirctures. (12)

\subsubsection{BE}

BE refers to the replacement of the multilayered SE with specialized intestinal type of columnar epithelium at the distal part of the esophagus. (13) Although the exact pathomechanism of $\mathrm{BE}$ is still unknown the major pathogenetic factors considered to be the excessive acid and bile exposure and the subsequent chronic inflammation triggered by the chemical injury. (14) The presence of Barrett-metaplastic tissue supposed to be an adaptive response to provide a better protection against chemical injury. (15) However, BE is associated with a 30- to 40-fold increased risk for the development of EAC, (16) a cancer whose incidence has rapidly increased in the past few decades in Western countries. (17) Based on this observation BE is considered to be the most severe complication of GERD, therefore its investigation and surveillence is necessary. $(18,19)$

\subsection{Pathogenesis of GERD}

Nearly all healthy individuals experience some sort of physiological reflux, which is generally short in duration and occurs infrequently, most typically in the postprandial period. (20) The refluxate may contain numerous substances such as bile acids and pancreatic enzymes, not 
only hydrochloric acid and pepsin. Under phyisological conditions, these injurious noxas are abolished by the defensive mechanisms of the esophagus. However, in patients with GERD, there is an imbalance between these aggressive and protective factors. Gastric acid is considered to be the most important contributing factor to GERD related symptoms and complications. Its pathogenic role is supported by the fact that GERD patients experience significantly increased acidic reflux (21) and acid supressing therapy has brought relief to GERD patients. (22) However, the severity of the disease cannot be explained by the gastric acid exposure alone. (21) Duodenogastric reflux contains high concentration of bile acids which have been shown to have carcinogenic properties by inducing epithelial proliferation and reducing the rate of apoptosis in EECs. (23) Moreover, the level of biliary reflux was not only shown to be increased in patients with specialized intestinal metaplasia (SIM) compared to those without SIM, but further significant increase has been demostrated in those with histological signs of dysplasia. (21) Bile acids were also shown to have a fundamental role in the development of columnar metaplasia by inducing the expression of CDX2 transciptional factor which is responsible for normal intestinal differentiation. $(24,25)$ Thus, bile acids are considered to be the other crucial pathogenic factor in the pathogensis of GERD related esophageal injury, especially BE and EAC. (22): To date, most papers have focused on the investigation of the direct effects of gastric acid and bile on EECs. (26-30). However, an alternative hypothesis has recently been emerged suggesting that beside the direct chemical challenge, cytokine-mediated inflammatory responses might have at least similarly important contribution in the development of esophageal mucosal injury in patients with GERD. $(31,32)$

\subsubsection{The role of ion transporters in the pathogenesis of GERD}

Under physiological conditions highly efficient barriers exist in the esophagus which can protect esophageal epithelium from harmful compounds. Epithelial resistance, which was first

described by Orlando et al. is one of the key element of the defense. (32) Esophageal resistance can be divided into three functional categories: the pre-epithelial, epithelial and post-epithelial defense. Pre-epithelial protection is consist of unstirred water layer and mucous layer with $\mathrm{HCO}_{3}{ }^{-}$ in it. The main role of this defense mechanism is to maintain a substantial $\mathrm{pH}$ gradient from lumen to surface cells. Post-epithelial defense refers to the adaquate blood supply of the tissue which plays an essential role in the regulation of interstitial $\mathrm{pH}$ through removal of acidic byproducts.(33) 
Epithelial defense is the most important component of esophageal resistence. It has both structural and functional components and the transport proteins on the apical and basolateral membranes of EECs play a crucial role in it. $(33,34)$ At the apical membrane of EECs, only a nonselective cation channel has been identified so far. (35) This channel is present in the SE of rabbits and has been shown equally permeable to $\mathrm{Na}^{+}, \mathrm{Li}^{+}, \mathrm{K}^{+}$, or even $\mathrm{H}^{+}$. The physiological role of this channel in esophageal epithelial function is poorly understood. Tobey et al. (36) have shown that acidic $\mathrm{pH}$ inhibits channel activity so $\mathrm{H}^{+}$cannot enter the cell through this channel and therefore may represent a protective mechanism against luminal acidity. Others suggest that this cation channel plays a role in cell differentiation. Blockade of this channel by acidic $\mathrm{pH}$ may inhibit the replenishment of polarized epithelial cells from undifferentiated basal cells. (35)

In contrast, at the basolateral membrane of SE several ion transporters have been identified. Tobey et al. (36) have shown the presence of a $\mathrm{Na}^{+}$-dependent and $\mathrm{Na}^{+}$-independent, disulfonic stilbene-sensitive, $\mathrm{Cl}^{-} / \mathrm{HCO}_{3}{ }^{-}$exchangers (CBE) on cultured rabbit SE. (37, 38) The $\mathrm{Na}^{+}$ independent $\mathrm{CBE}$ mediates the efflux of $\mathrm{HCO}_{3}{ }^{-}$into the lumen, which results in the acidification of the $\mathrm{pH}_{\mathrm{i}}$. In contrast, the $\mathrm{Na}^{+}$-dependent $\mathrm{CBE}$ operates in a reverse mode and promotes the influx of $\mathrm{HCO}_{3}{ }^{-}$in exchange for intracellular $\mathrm{Cl}^{-}$and therefore contributes to the alkalization of the cell. $(37,38)$ Beside the CBEs, an amiloride-sensitive $\mathrm{Na}^{+} / \mathrm{H}^{+}$exchanger (NHE) has also been identified on the basolateral membrane of rat, rabbit and human SE. (37, 39, 40) Among the nine known NHE isoforms, NHE1 has been shown to be present on EECs using reverse-transcription-PCR and Western blot. The major role of NHE1 in the esophagus is the regulation of $\mathrm{pH}_{\mathrm{i}}$ by the electroneutral exchange of intracellular $\mathrm{H}^{+}$to extracellular $\mathrm{Na}^{+}$. In addition, NHE1 is also important in several defensive mechanisms such as cell volume regulation, proliferation, and cell survival. (41-43)

These studies have been performed on normal esophageal epithelium; however, the activity or expression of ion transporters in the columnar epithelia under pathophysiological conditions is less characterized. (44)

\subsubsection{The role of autophagy in the pathogenesis of GERD and BE}

Autophagy is a lysosome dependent cellular mechanism which degrades the damaged or obsolete organelles and proteins in the cells. (45) Basal level of autophagy has a fundamental physiological role in cellular homeostasis like development, immune defense, programmed cell 
death and prevention of neuron degradation. (45) Furthermore, autophagy is induced as an adaptive response to cellular stress, either from nutrient/growth factor deprivation, hypoxia, oxidative stress, accumulation of protein aggregates, and endoplasmic reticulum stress. (46, 47) During autophagy the potentially toxic cytoplasmic constituents are encapsulated by pre-autophagosomalstructures called "phagophores" that mature into double-membrane vesicles called "autophagosomes" and fuse with lysosomes where the content is degraded. (48)

In normal tissues, autophagy is responsible for maintaining cell homeostasis and prevents carcinogenesis $(49)$ by inducing apoptosis. $(48,50,51)$ Therefore, the dysregulation of autophagy has been linked to a growing list of diseases such as eosinophilic esophagitis (52), inflammatory bowel disease (53) and Parkinson's disease (54). Autophagy can also act as a double edged sword in the cells: once cancer develops, many cancer cells upregulate autophagy to survive hypoxia and nutrient limitation. (48) Interestingly, despite the growing evidence between cancer and autophagy, the importance of autophagy in pre-cancerous lesions like BE is less established. Furthermore, in GERD, the gastric acid and bile contribute to the inflammation and cellular stress of esophageal epithelium which are important activators of autophagy. (27, 55-57) In contrast, to date there is only a single publication on the role of autophagy in BE mainly focusing on the role of Beclin1 autophagy gene only. (58)

\subsubsection{Modeling the pathogenesis of GERD}

Research into GERD and its complications has been restricted by the availability of suitable laboratory approaches to model these conditions. Much of the past work has relied upon the availability of human patient biopsies, which are difficult to obtain and primarily suitable for descriptive studies. Immortalized cell lines, representing normal squamous, Barrett's, and EAC are available (59-62), however 2D cultured cells can not effectively model complex interactions between epithelial cells and their microenvironment. (14) Animal models are another important tool of biomedical research. However, animal models for the diseases of the esophagus are limited as well, in part due to anatomic differences between mice and humans at the squamo-columnar junction. (63) OTC system is an innovative multicellular system which attempts to better model human tissues. (64) Under 3D OTC conditions, human esophageal keratinocytes undergo a complete differentiation and stratification producing a fully mature epithelium. Its advantage relates to the normal polarization and differentiation of cells and gene expression patterns are 
similar to the in vivo conditions. OTC is an in vitro tool which is still physiologically relevant and helps to understand better the complex interactions between epithelial cells and their microenvironment.

\section{AIMS}

The specific aims of our studies:

I. In the first part of the thesis we attempted to identify the ion transport mechanisms in columnar epithelial cells derived from Barrett's metaplasia and to characterize the effect of main internal risk factors (such as $\mathrm{HCl}$, bile acids) on these transporters. Furthermore, we aimed to compare their mRNA and protein expression profile of ion transporters with human squamous and columnar epithelial cells obtained from endoscopic biopsies of normal esophageal mucosa and BE.

II. In the second part of the thesis, we planned to explore the functional role of the autophagic response in cellular oxidative stress and cell survival in esophageal cells representing different severity stages of adenocarcinoma in an in vitro model of acid reflux.

III. Finally, our last objective was to establish whether OTC could be applied as a novel platform for the study of inflammatory environment in GERD. 


\section{MATERIALS AND METHODS}

\subsection{Cell lines}

Immortalized human squamous EECs (STR, University of Pennsylvania, Philadelphia, PA, USA) were developed and maintained as previously described. (65) CP-A human, non-dysplastic Barrett's esophageal cell line was obtained from American Type Culture Collection (ATCC, Manassas, VA, USA). CP-D human, dysplastic Barrett's cell line was kindly provided by Peter Rabinovich (University of Washington). CP-A and CP-D cells were adapted to serum-free conditions in keratinocyte serum-free medium (KSFM, Invitrogen, Waltham, MA, USA). OE19 human adenocarcinoma cells were purchased from Sigma-Aldrich (Saint Louis, MO, USA) and maintained in RPMI 1640 with 2 mM glutamine and 10\% fetal calf serum. Medium was replaced in every 2 days on all cell lines. Cultures were continually incubated at $37^{\circ} \mathrm{C}$ and gassed with the mixture of $5 \% \mathrm{CO}_{2}$ and $95 \%$ air. Lentiviral vector LC3-GFP was obtained from Dr Craig Thompson (Memorial Sloan Kettering, New York, NY, USA) and transfected into 293T cells along with the packaging plasmids using Lipofectamine 2000 (Invitrogen, Waltham, MA, USA) reagent following the manufacturer's instructions. Then OE19 cells were exposed to virus in the presence of $8 \mathrm{mg} / \mathrm{mL}$ polybrene for 16-18h respectively. LC3-GFP expressing cell populations were isolated by sorted for GFP using flow cytometry. LC3-GFP expression was confirmed by examination of the cells by confocal fluorescent microscopy on a Nikon Eclipse Ti-U microscope. LC3-GFP+ vesicles were identified and quantified using the spot finder application in the Volocity image analysis software package (Perkin Elmer, Waltham, MA, USA)

\subsection{3-dimensional organotypic culture (3D OTC)}

The fibroblast feeder layer and $6.75 \times 10^{5}$ PBMCs were embedded within a collagen/Matrigel matrix and was allowed to mature for 7 days, after which $5 \times 10^{5}$ epithelial cells were seeded on top and allowed to grow confluence for another 4 days. On day 11, the culture media level is reduced bringing the keratinocytes to air-liquid interface which stimulates epithelial differentiation into a multilayer epithelium typical for the esophagus. On day 15, OTCs were harvested for histology, RNA and/or protein isolation. (Fig.1.) 


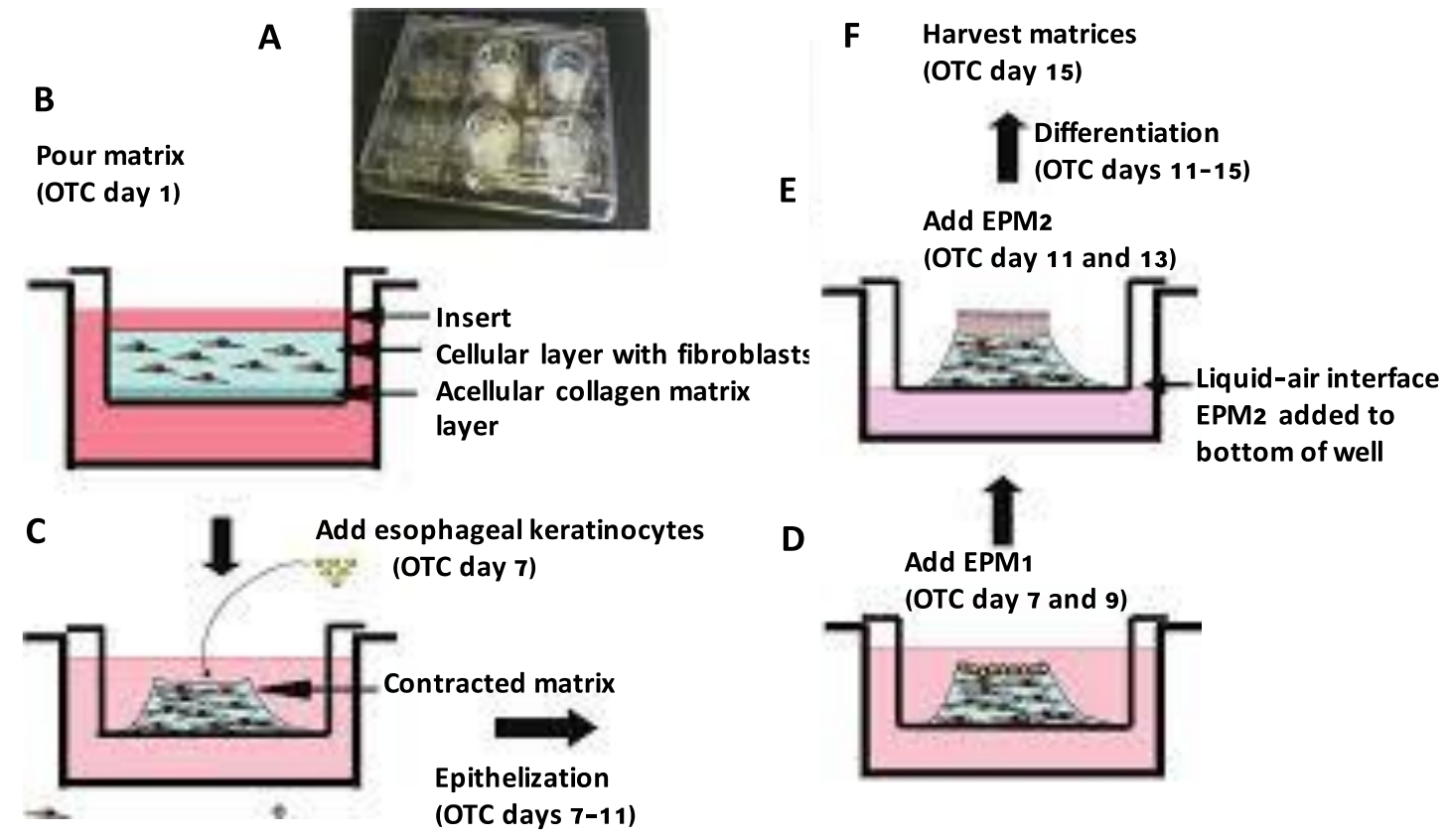

Figure 1. Establishment of organotypic culture (OTC) system (adapted from Kalabis et al. Nat. Protoc. 2012) (A) Inserts are placed on 6-well plates. (B) In the first step, there is placement of an acellular collagen matrix on the bottom of an insert, followed by the addition of a layer of esophageal fibroblasts embedded in collagen. They are cultured initially for 7 days, allowing for fibroblast-mediated constriction of the collagen matrix. (C) On day 7, the EECs are seeded on the top of the contracted matrix. (D) The epithelization medium (EPM) 1 of the OTC is changed every 2 days. (E) On day 11, the level of the medium (EPM2) is reduced, therefore the epithelium is exposed to air to create a liquid-air interface $(\mathbf{E})$, thereby promoting epithelial stratification and differentiation. (F) Finally, on day 15, the resulting OTC is harvested for histology and RNA/protein analyses.

\subsection{Immune cells and cytokine treatment}

PBMCs were collected from healthy volunteers and isolated freshly by the Human Immunology Core at the University of Pennsylvania. To model $\mathrm{T}_{\mathrm{H}} 1$ inflammatory environment pro-inflammatory cytokines IL-7 (10 ng/mL, Cell Signaling, Beverly, MA, USA) and IL-15 (20 ng/mL, ProSpec Rehovot, Israel) were included to the cell culture media; IL-2 (10 U/mL, BD Biosciences, San Jose, CA, USA) was also added to support PBMC viability. The cytokines were replenished during each media change. 


\subsection{Patients}

Fourteen patients with endoscopic evidence of esophageal metaplasia were enrolled in the First Department of Medicine, University of Szeged, Hungary. Endoscopic procedures were carried out by standard, high resolution, white-light endoscopes (Olympus GIF-Q165) and the Prague C\&M criteria were applied for the description of esophageal metaplasia. (66) Four biopsy samples were obtained from the macroscopically visible metaplastic columnar epithelium of the esophagus and another four from the normal squamous lining. Two of each sample were formalinfixed and submitted for histological evaluation including IHC. The remaining two samples were immediately placed and stored in RNA-later solution for real-time PCR analysis at $-20^{\circ} \mathrm{C}$. All procedures were performed with informed patient consent and under approved human subject's protocols from University of Szeged (No.: 2348).

\subsection{Chemicals and solutions}

General laboratory chemicals and bile acid salts were obtained from Sigma-Aldrich (Budapest, Hungary). 2,7-bis-(2-carboxyethyl)-5(6)-carboxyfluorescein acetoxymethyl ester (BCECF-AM), 2-(6-(bis(carboxymethyl)amino)-5-(2-(2-(bis(carboxymethyl)amino)-5methylphenoxy)ethoxy)-2-benzofuranyl)-5-oxazolecarboxylic acetoxymethyl ester (Fura-2 AM), 1,2-bis(o-aminophenoxy)ethane-N,N,N9,N9-tetraacetic acid (BAPTA-AM), 4,4'diisothiocyanatodihydrostilbene-2,2'-disulfonic acid, disodium salt $\left(\mathrm{H}_{2} \mathrm{DIDS}\right)$ were from Molecular Probes Inc (Eugene, OR, USA). BCECF-AM ( $2 \mu \mathrm{mol} / 1)$ and BAPTA-AM (40 $\mu \mathrm{mol} / 1)$ were prepared in dimethyl sulfoxide (DMSO), whereas FURA-2-AM (5 $\mu \mathrm{mol} / 1)$ was dissolved in DMSO, containing $20 \%$ pluronic acid. 4-isopropyl-3-methylsulphonylbenzoyl-guanidin methanesulphonate (HOE-642) was provided by Sanofi Aventis (Frankfurt, Germany) and was dissolved in DMSO. Nigericin $(10 \mathrm{mM})$ was prepared in ethanol and stored at $-20{ }^{\circ} \mathrm{C}$.

The compositions of the solutions used are shown in Table 1. Standard HEPES-buffered solutions were gassed with $100 \% \mathrm{O}_{2}$ and their $\mathrm{pH}$ was set to 7.4 with $\mathrm{NaOH}$. Standard $\mathrm{HCO}_{3}-/ \mathrm{CO}_{2}$-buffered solutions were gassed with $95 \% \mathrm{O}_{2} / 5 \% \mathrm{CO}_{2}$ to set $\mathrm{pH}$ to 7.4. All experiments were performed at $37^{\circ} \mathrm{C}$. 


\begin{tabular}{|c|c|c|c|c|c|c|c|}
\hline & $\begin{array}{c}\text { Standard } \\
\text { Hepes }\end{array}$ & $\begin{array}{c}\text { Standard } \\
\mathrm{HCO}_{3}^{-}\end{array}$ & $\begin{array}{l}\mathrm{NH}_{4} \mathrm{Cl} \\
\text { Hepes }\end{array}$ & $\begin{array}{l}\mathrm{NH}_{4} \mathrm{Cl} \\
\mathrm{HCO}_{3}^{-}\end{array}$ & $\begin{array}{c}\mathrm{Na}^{+} \text {-free } \\
\text { Hepes }\end{array}$ & $\begin{array}{l}\mathrm{Cl}^{-} \text {-free } \\
\text { Hepes }\end{array}$ & $\begin{array}{l}\mathrm{Cl}^{-} \text {-free } \\
\mathrm{HCO}_{3}^{-}\end{array}$ \\
\hline $\mathrm{NaCl}$ & 130 & 115 & 110 & 95 & & & \\
\hline $\mathrm{KCl}$ & 5 & 5 & 5 & 5 & 5 & & \\
\hline $\mathrm{MgCl}_{2}$ & 1 & 1 & 1 & 1 & 1 & & \\
\hline $\mathrm{CaCl}_{2}$ & 1 & 1 & 1 & 1 & 1 & & \\
\hline Na-Hepes & 10 & & 10 & & & & \\
\hline Glucose & 10 & 10 & 10 & 10 & 10 & 10 & 10 \\
\hline $\mathrm{NaHCO}_{3}$ & & 25 & & 25 & & & 25 \\
\hline $\mathrm{NH}_{4} \mathrm{Cl}$ & & & 20 & 20 & & & \\
\hline Hepes & & & & & & 10 & \\
\hline NMDG-Cl & & & & & 10 & & \\
\hline $\begin{array}{l}\mathrm{Na}- \\
\text { gluconate }\end{array}$ & & & & & 140 & 140 & 115 \\
\hline $\begin{array}{l}\text { Mg- } \\
\text { gluconate }\end{array}$ & & & & & & 1 & 1 \\
\hline $\begin{array}{l}\text { Ca- } \\
\text { gluconate }\end{array}$ & & & & & & 6 & 6 \\
\hline K-sulfate & & & & & & 5 & 2.5 \\
\hline
\end{tabular}

Table 1.: Composition of solutions. Values are in mM.

\subsection{Measurement of $\mathrm{pH}_{\mathrm{i}}$ and $\left[\mathrm{Ca}^{2+}\right]_{\mathrm{i}}$ with microfluorimetry}

150.000-250.000 cells were seeded to $24 \mathrm{~mm}$ cover slips which were mounted on the stage of an inverted fluorescence microscope linked to an Xcellence imaging system (Olympus, Budapest, Hungary). Cells were bathed with different solutions at $37^{\circ} \mathrm{C}$ at the perfusion rate of 5-6 ml/min. 6-7 cells/region of interests (ROIs) were examined in each experiments and one measurement per second was obtained. In order to estimate $\mathrm{pH}_{\mathrm{i}}$ cells were loaded with the $\mathrm{pH}$ sensitive fluorescent dye, BCECF-AM for 20-30 min at room temperature. Cells were excited with 490 and $440 \mathrm{~nm}$ wavelengths, and the 490/440 fluorescence emission ratio was measured at $535 \mathrm{~nm}$. The calibration of the fluorescent emission ratio to $\mathrm{pH}_{\mathrm{i}}$ was performed with the high$\mathrm{K}^{+}$-nigericin technique, as previously described. $(67,68)$ To determine the changes of $\left(\left[\mathrm{Ca}^{2+}\right]_{\mathrm{i}}\right)$ 
cells were incubated with FURA2-AM and pluronic acid for 50-60 min. For excitation, 340 and $380 \mathrm{~nm}$ filters were used, and the changes in $\left[\mathrm{Ca}^{2+}\right]_{\mathrm{i}}$ were calculated from the $340 / 380$ fluorescence ratio measured at $510 \mathrm{~nm}$.

\subsection{Determination of buffering capacity and base efflux}

The total buffering capacity ( $\left.\beta_{\text {total }}\right)$ of cells was estimated according to the $\mathrm{NH}_{4}{ }^{+}$prepulse technique, as previously described.(69, 70) Briefly, EECs were exposed to various concentrations of $\mathrm{NH}_{4} \mathrm{Cl}$ in a $\mathrm{Na}^{+}-$and $\mathrm{HCO}_{3}{ }^{-}$-free solutions. The total buffering capacity of the cells was calculated using the following equation: $\beta_{\text {total }}=\beta_{\mathrm{i}}+\beta_{\mathrm{HCO} 3-}=\beta_{\mathrm{i}}+2.3 \times\left[\mathrm{HCO}_{3}{ }^{-}\right]_{\mathrm{i}}$, where $\beta_{\mathrm{i}}$ refers to the ability of intrinsic cellular components to buffer changes of $\mathrm{pH}_{\mathrm{i}}$ and was estimated by the Henderson-Hasselbach equation. $\beta_{\mathrm{HCO} 3}$ is the buffering capacity of the $\mathrm{HCO}_{3}{ }^{-} / \mathrm{CO}_{2}$ system. The measured rates of $\mathrm{pH}_{\mathrm{i}}$ change $(\Delta \mathrm{pH} / \Delta \mathrm{t})$ were converted to transmembrane base flux $J\left(\mathrm{~B}^{-}\right)$using the equation: $J\left(\mathrm{~B}^{-}\right)=\Delta \mathrm{pH} / \Delta \mathrm{t} \times \beta_{\text {total }}$. The $\beta_{\text {total }}$ value at the start point $\mathrm{pH}_{\mathrm{i}}$ was used for the calculation of $J\left(\mathrm{~B}^{-}\right)$. We denote base influx as $J(\mathrm{~B})$ and base efflux (secretion) as $-J\left(\mathrm{~B}^{-}\right)$.

\subsection{Measurement of the activity of NHE, NBC and CBE}

In order to estimate the activity of $\mathrm{NHEs}$, the $\mathrm{NBC}$ and $\mathrm{CBE}$ the $\mathrm{NH}_{4} \mathrm{Cl}$ prepulse technique was used. Briefly, exposure of esophageal cells to $20 \mathrm{mM} \mathrm{NH}_{4} \mathrm{Cl}$ for 3 min induced an immediate rise in $\mathrm{pH}_{\mathrm{i}}$ due to the rapid entry of lipophilic, basic $\mathrm{NH}_{3}$ into the cells. After the removal of $\mathrm{NH}_{4} \mathrm{Cl}$, $\mathrm{pH}_{\mathrm{i}}$ rapidly decreased. This acidification is caused by the dissociation of intracellular $\mathrm{NH}_{4}{ }^{+}$to $\mathrm{H}^{+}$ and $\mathrm{NH}_{3}$, followed by the diffusion of $\mathrm{NH}_{3}$ out of the cell. In standard Hepes-buffered solution the initial rate of $\mathrm{pH}_{\mathrm{i}}(\Delta \mathrm{pH} / \Delta \mathrm{t})$ recovery from the acid load (over the first $60 \mathrm{sec}$ ) reflects the activities of NHEs, whereas in $\mathrm{HCO}_{3}{ }^{-} / \mathrm{CO}_{2}$-buffered solutions represents the activities of both NHEs and NBC.(69)

Two independent methods have been performed in order to estimate CBE activity. Using the $\mathrm{NH}_{4} \mathrm{Cl}$ prepulse technique the initial rate of $\mathrm{pH}_{\mathrm{i}}$ recovery from alkalosis in $\mathrm{HCO}_{3}{ }^{-} / \mathrm{CO}_{2}{ }^{-}$buffered solutions was analyzed.(69) Previous data have indicated that under these conditions the recovery over the first 30 seconds reflects the activity of CBE. (69) The $\mathrm{Cl}^{-}$withdrawal technique was also applied, where removal of $\mathrm{Cl}^{-}$from the external solution causes an immediate and reversible alkalisation of the $\mathrm{pH}_{\mathrm{i}}$ due to the reverse operation of $\mathrm{CBE}$ under these conditions. Previous data 
have shown that the initial rate of alkalisation over the first 60 seconds reflects the activity of CBE. (71)

\subsection{Bile acid treatments}

In order to mimic the chronic bile acid exposure in GERD in vitro, cells were treated with bile acid cocktail (BAC) at $\mathrm{pH} 7.5$ and 5.5. Two days prior to bile acids treatment, cells were seeded at $10^{6}$ cells $/ 75 \mathrm{~cm}^{2}$ tissue culture flasks and were grown to $70-80 \%$ of confluence. On the second day, after the seeding, cells were treated with bile acids for 10 min pulses, 3 times a day up to 7 days. The compostion of BAC was: $170 \mu \mathrm{M}$ glycocholic acid (GC), $125 \mu \mathrm{M}$ glycochenodeoxycholic acid (GCDC), $100 \mu \mathrm{M}$ deoxycholic acid (DC), $50 \mu \mathrm{M}$ glycodeoxycholic acid (GDC), $25 \mu \mathrm{M}$ taurocholic acid (TC), $25 \mu \mathrm{M}$ taurochenodeoxycholic acid (TCDC) and $8 \mu \mathrm{M}$ taurodeoxycholic acid (TDC). The composition and concentration of BAC mimics the bile acid profile of GERD. (72-74)

\subsection{RNA isolation, reverse transcription and quantitative real-time PCR}

Total RNA was purified from individual cell cultures, biopsy samples and OTC epithelium (after manually peeling off from the collagen base) using the RNA isolation kit of Macherey-Nagel (Nucleospin RNA II kit, Macherey-Nagel, Düren, Germany) according to the manufacturer's instructions. The quantity of isolated RNA samples was checked by spectrophotometry (NanoDrop 3.1.0, Rockland, DE, USA). High-Capacity cDNA Archive Kit (Applied Biosystems Foster City, CA, USA) was used for reverse transcription according to the manufacturer's instructions. For NHE-1, 2, NBC, Slc26a6 genes, reactions were performed on RotorGene 3000 instrument (Corbett Research, Sydney, Australia) using Taqman probe sets (Applied Biosystems Foster City, CA, USA). Hypoxanthine-guanine phosphoribosyltransferase (HPRT) gene was used as an internal control. For IRF-1 gene reaction was performed using the StepOne Plus instrument and the amplifications were done using the SYBR Green PCR Master Mix (Applied Biosystems, Foster City, CA, USA). GAPDH was used as the normalization control. In the case of cell lines, and OTC epithelium the relative changes in gene expression were determined using the $\Delta \Delta \mathrm{C}_{\mathrm{T}}$ method as described in Applied Biosystems User Bulletin No. 2 (P/N 4303859). In the case of biopsy samples, the relative expression values of NHE1, NHE2, NBC and SLC26a6 in normal and BE samples 
was used to create box plots. In order to compare the expression of genes between normal and $\mathrm{BE}$ samples, Wilcoxon test was used.

\subsection{Western Blot analysis}

$20 \mu \mathrm{g}$ of denatured protein was fractionated on a NuPAGE Bis-Tris 4-12\% gel (Life Technologies, Carlsbad, CA, USA). Following electrotransfer, Immobilon-P membranes (Millipore, Billerica, MA, USA) were blocked with PBST containing 5\% milk, followed by overnight incubation with the following primary antibodies: rabbit anti-NHE1 (1:200, Alomone Laboratories, Jerusalem, Israel) and IRF-1 (1:1000 Abcam, Cambridge, MA, USA) at $4^{\circ} \mathrm{C}$. Mouse anti-GAPDH (1:10000 Merck Millipore, Billerica, MA, USA) and mouse alpha tubulin (1:10000 Sigma-Aldrich, Saint Louis, MO, USA) were used as an internal control. Targeted proteins were visualized using a chemiluminescence detection system (Amersham ECL or ECL Prime; GE Healthcare Life Sciences, Pittsburgh, PA, USA)

\subsection{Immunohistochemistry}

$5 \mu \mathrm{m}$ paraffin-embedded sections of human, esophageal biopsy samples and OTCs were deparaffinised, and heat mediated antigen retrieval was performed with $10 \mathrm{mmol} / \mathrm{L}$ citric acid buffer (pH 6.0). Endogenous peroxidases were quenched using hydrogen peroxide before sections

were incubated in avidin D and biotin blocking reagents. Sections were incubated with primary mouse monoclonal anti-NHE1 (1:100, Abcam, Cambridge, MA, USA), chicken anti-NHE2 (1:50, Chemicon, Temecula, CA, USA), rabbit anti-CD45 (1:50, Abcam, Cambridge, MA, USA), rabbit anti-Ki-67 (1:200, Abcam, Cambridge, MA, USA) antibodies and biotinylated secondary antibodies and an avidin-horseradish peroxidase conjugate (Vectastain Elite ABC kit; Vector Laboratories, Burlingame, CA, USA) following the manufacturer's protocol. The signal was developed using the 3,39-diaminobenzidine substrate kit (Vector Laboratories, Burlingame, CA, USA). Sections were counterstained with hematoxylin. The specificity of the primary antibodies was assessed by using mouse IgG1 or chicken IgY isotype controls. Slides were visualized under Nikon E600 brightfield microscope (Melville, NY, USA) and digital images were taken with iVision software (Atlanta, GA, USA). All images were analyzed with ImageJ software. 


\subsection{TUNEL assay}

Apoptosis in paraffin-embedded sections was assessed using In Situ Cell Death Detection Kit (Roche, Indianapolis, IN, USA) according to the manufacturer's instructions.

\subsection{Flow cytometry analysis}

To detect autophagy flux Cyto-ID ${ }^{\circledR}$ (Enzo Life Sciences, Farmingdale, NY, USA) green autophagy dye was used according to the manufacturer's instruction. Cells were trypsinized into single cells and stained with Cyto-ID for $30 \mathrm{~min}$ at $37^{\circ} \mathrm{C}$ prior to analysis. Intracellular levels of ROS in epithelial cells were determined by flow cytometry with 2', 7'-dichlorodihydrofluorescein diacetate (DCF) dye (Life Technologies, Carlsbad, CA, USA). DCF is lipophilic and nonfluorescent compound that is oxidized to fluorescent DCF by ROS, and is widely used to evaluate cellular oxidative stress. For cell lines, cells were incubated with $10 \mu \mathrm{M} \mathrm{DCF}$ at $37^{\circ} \mathrm{C}$ for $30 \mathrm{~min}$ and further cultured for up to $3 \mathrm{~h}$ prior to analysis. OTCs were incubated with $10 \mu \mathrm{M} \mathrm{DCF}$ at $37^{\circ} \mathrm{C}$ for $60 \mathrm{~min}$ and further cultured for up to 3 hours prior to peeling the epithelial layer and trypsinizing into single cells. Cell death measures, at $24 \mathrm{~h}$ were carried out using staining with 7 amino-actinomycin D (7AAD, Biolegend, San Diego, CA, USA). 7AAD fluoresces upon binding to DNA and is normally excluded by living, intact cells. After cells were isolated from the culture plate, washed, and centrifuged, they were resuspended in $0.5 \mathrm{~mL}$ of FACS buffer and 5ul of 7AAD and further incubated for 5-10 min in the dark before the analysis and quantitation by flow cytometry. Following stainings, cells were washed then analyzed in DPBS containing 1\% BSA using a FACS Calibur (BD Biosciences, San Jose, CA, USA). FlowJo software (Tree Star, Ashland, OR, USA) was used for data analysis.

\subsection{Statistical analysis}

GraphPad Prism (San Diego, CA, USA) software was used for statistical analyses. Unpaired student's t-test was used for comparisons between two groups. Data from multiple groups were analyzed using one-way ANOVA with Tukey's post-hoc test. All data were represented as mean \pm standard error of the mean (SEM). $p$ values $\leq 0.05$ were accepted as significant. 


\section{RESULTS}

\subsection{Role of ion transporters in the bile acid-induced esophageal injury}

\subsubsection{The main $\mathrm{pH}_{\mathrm{i}}$ regulatory mechanisms in human EECs}

In the first series of experiments, the resting $\mathrm{pH}_{\mathrm{i}}$ of $\mathrm{CP}-\mathrm{A}$ and $\mathrm{CP}-\mathrm{D}$ cell lines was calibrated by the high $\mathrm{K}^{+} /$nigericin method. (68) Briefly, cells were exposed to standard HEPES solution (pH 7.4), followed by a 5 -minutes incubations to a high $\mathrm{K}^{+} /$nigericin-Hepes solution at $\mathrm{pH} 7.28,7.4$ and 7.6. The classical linear model was used to determine the resting $\mathrm{pH}_{\mathrm{i}}$ of the cells. $(67,68)$ The resting $\mathrm{pH}_{\mathrm{i}}$ levels of $\mathrm{CP}$-A and $\mathrm{CP}-\mathrm{D}$ were $7.32 \pm 0.03$ and $7.31 \pm 0.03$, respectively. The resting $\mathrm{pH}_{\mathrm{i}}$ did not differ significantly among the $\mathrm{pH}$ experiments. (data not shown)

In the next step, the major functionally active ion transporters in Barrett's derived cells (CP-A and CP-D) were characterized. $\mathrm{Na}^{+}$-withdrawal from the standard Hepes-buffered solution resulted in a rapid intracellular acidification (Fig. 2A) in CP-A cells which is likely due to the inhibition of NHE. To further confirm the presence of $\mathrm{NHE}, \mathrm{NH}_{4} \mathrm{Cl}$ prepulse technique was used as it has been described in Materials and Methods. When $\mathrm{Na}^{+}$was removed from the external solution the recovery of $\mathrm{pH}_{\mathrm{i}}$ was completely abolished. (Fig. 2B) Similar results were confirmed in CP-D cells, suggesting that these cells also possess functionally active NHE.

A.

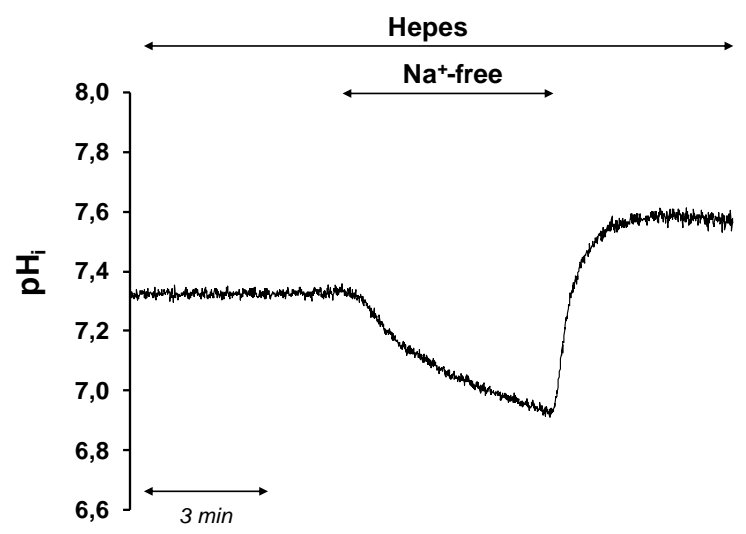

B.

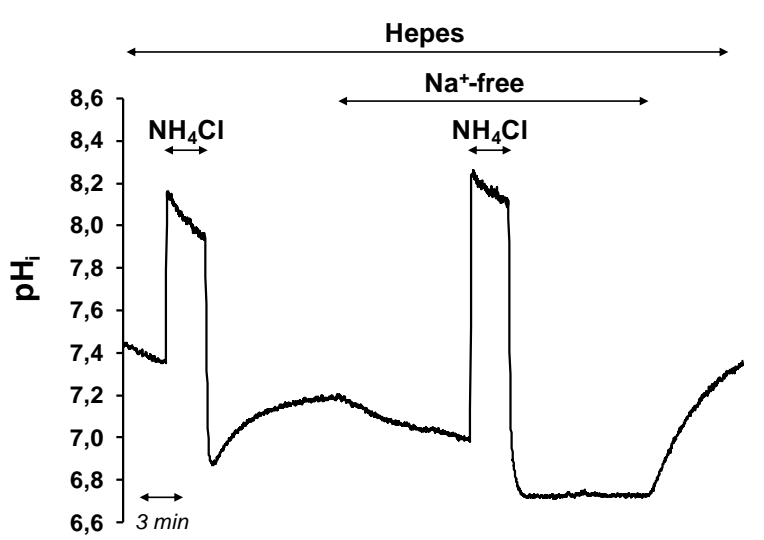

Figure 2. Investigation of NHE activity on CP-A cells. (A) Removal of $\mathrm{Na}^{+}$from the standard HEPES solution caused a rapid and marked intracellular acidosis in CP-A cells, which confirms the presence of a $\mathrm{Na}^{+}$-dependent $\mathrm{H}^{+}$ efflux mechanism. (B) Recovery from acid load reflects the activity of NHE in standard HEPES-buffered solution. In the case of the second $\mathrm{NH}_{4} \mathrm{Cl}$ pulse, $\mathrm{Na}^{+}$was removed from the external solution, 10 min before the pulse started, during the $\mathrm{NH}_{4} \mathrm{Cl}$ pulse, and 10 min after the pulse. 
To date, 9 members of the NHE family have been identified, all of which display different regulation and expression pattern in the human body. Functional measurements were performed to determine which NHE isoforms are present in CP-A and CP-D cells using the isoform selective NHE inhibitor, HOE-642. At $1 \mu \mathrm{M}$, HOE-642 inhibits only NHE1, whereas at $50 \mu \mathrm{M}$ inhibits both NHE1 and NHE2. Using the $\mathrm{NH}_{4} \mathrm{Cl}$ prepulse technique it was shown that $1 \mu \mathrm{M} \mathrm{HOE}-642$ inhibited the recovery from acid load by $77.3 \pm 3.0 \%$ in CP-A and $70.0 \pm 0.3 \%$ in CP-D cells, whereas in the presence of $50 \mu \mathrm{M}$ HOE-642, the recovery was completely abolished in both cell lines. (Fig. $3 \mathrm{~A}$ and $\mathrm{B}$ )

A

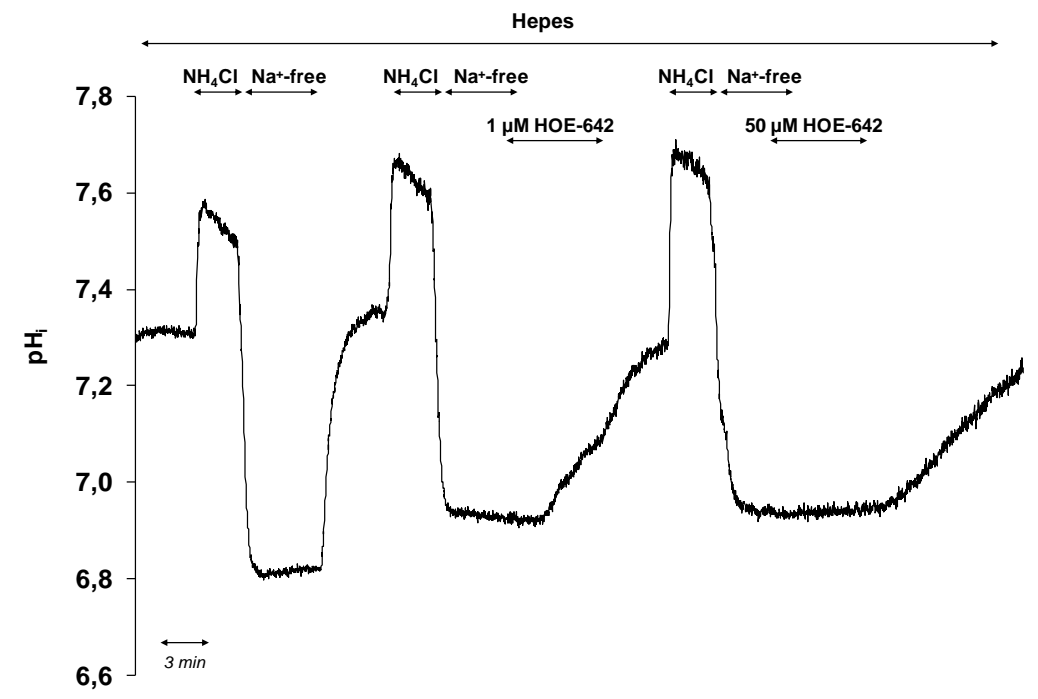

B

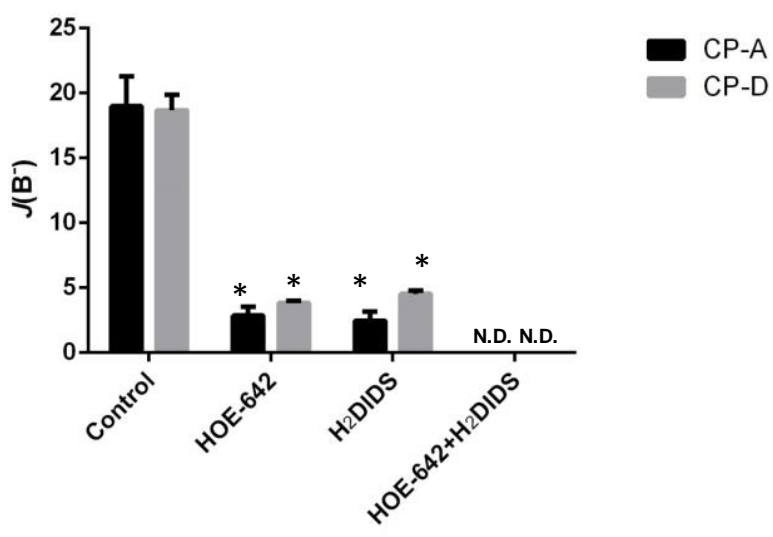

Figure 3. Investigation of different NHE isoform activity on EECs. (A) Representative $\mathrm{pH}_{\mathrm{i}}$ curve shows the recovery from acid load in the presence of 1 and $50 \mu \mathrm{M}$ HOE-642. (B) Summary data of the calculated activities of the different NHE isoforms in the presence of isoform selective NHE inhibitor, HOE-642. The rate of acid recovery $\left[J\left(\mathrm{~B}^{-}\right)\right]$was calculated from the $\Delta \mathrm{pH} / \Delta t$ obtained by linear regression analysis of $\mathrm{pH}_{\mathrm{i}}$ measurements made over the first 60 $\mathrm{s}$ of recovery from the lowest $\mathrm{pH}_{\mathrm{i}}$ level (start point $\mathrm{pH}_{\mathrm{i}}$ ). The buffering capacity at the start point $\mathrm{pH}_{\mathrm{i}}$ was used for the calculation of $J\left(\mathrm{~B}^{-}\right)$. N.D., not detected. Data are presented as means $\pm \mathrm{SE}$. $* P \leq 0.05$ vs. control; $n=15-25$. 
$\mathrm{NBC}$ represents another important $\mathrm{pH}_{\mathrm{i}}$ regulatory mechanism in several types of epithelial cells (75-77). In the case of EECs, in standard $\mathrm{HCO}_{3}{ }^{-} / \mathrm{CO}_{2}$-buffered extracellular solution, the $\mathrm{pH}$ of CP-A cells rapidly decreased by the quick diffusion of $\mathrm{CO}_{2}$ into the cytoplasm. (Fig. 4A) A low level of $\mathrm{pH}_{\mathrm{i}}$ recovery was found after acidosis, which is probably due to the influx of $\mathrm{HCO}_{3}{ }^{-}$into the cells through NBC. Removal of $\mathrm{Na}^{+}$resulted in the same level of acidification as in the standard Hepes-buffered solution. (Fig. 4A) To further confirm the presence of NBC, the effect of $\mathrm{H}_{2} \mathrm{DIDS}$, an inhibitor of both NBC and CBE on the recovery from $\mathrm{CO}_{2}$-induced acidosis was investigated. $500 \mu \mathrm{M} \mathrm{H}_{2}$ DIDS completely inhibited the regeneration from acidosis (Fig. 4B). However, after the removal of $\mathrm{H}_{2}$ DIDS from the external solution, the $\mathrm{pH}_{\mathrm{i}}$ completely recovered. Since CBE did not affect the recovery from acidosis (see Fig. 4A), these results strongly suggest the presence of functionally active NBC in CP-A cells. Using the same experimental protocol, the presence of NBC was also confirmed in CP-D cells.

A

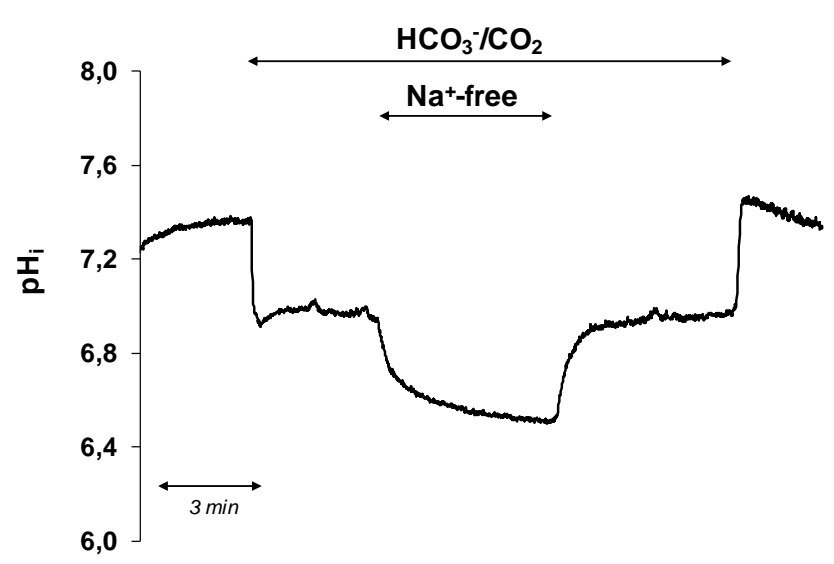

B

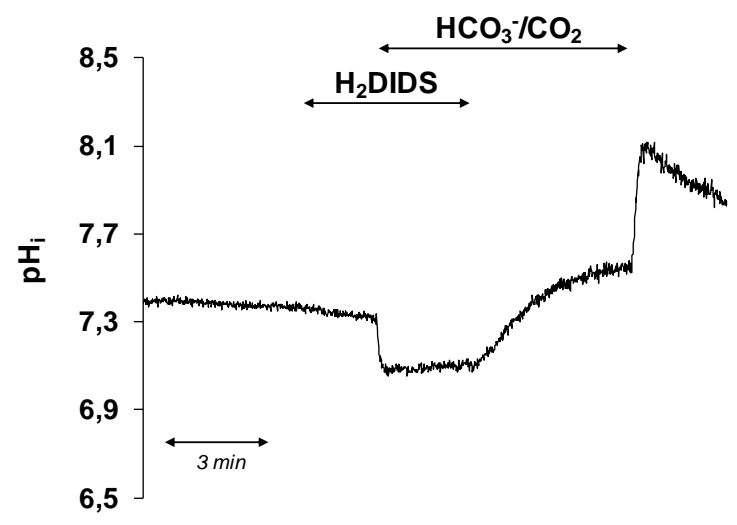

Figure 4. Investigation of NBC activity on EECs. (A) Representative $\mathrm{pH}_{\mathrm{i}}$ curve showing the effect of $\mathrm{Na}^{+}$removal on CP-A cells in $\mathrm{HCO}_{3}{ }^{-} / \mathrm{CO}_{2}$-buffered solution. (B) Administration of $500 \mu \mathrm{M} \mathrm{H}_{2}$ DIDS completely abolished the recovery from acidosis in $\mathrm{CP}-\mathrm{A}$ cells.

In order to estimate the activities of NHE and NBC, the effects of $\mathrm{H}_{2}$ DIDS $(500 \mu \mathrm{M})$ and HOE-642 $(50 \mu \mathrm{M})$ on the recovery from acid load was tested separately and together. Both $\mathrm{H}_{2}$ DIDS and HOE-642 equally reduced the recovery from acidosis, whereas combined administration of these two agents completely abolished it. (Fig. 5A and B) 
A

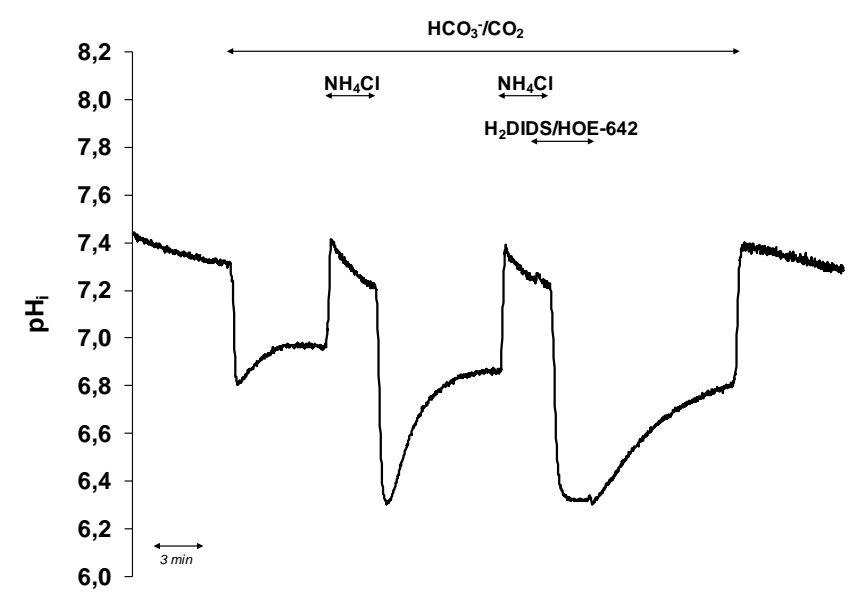

B

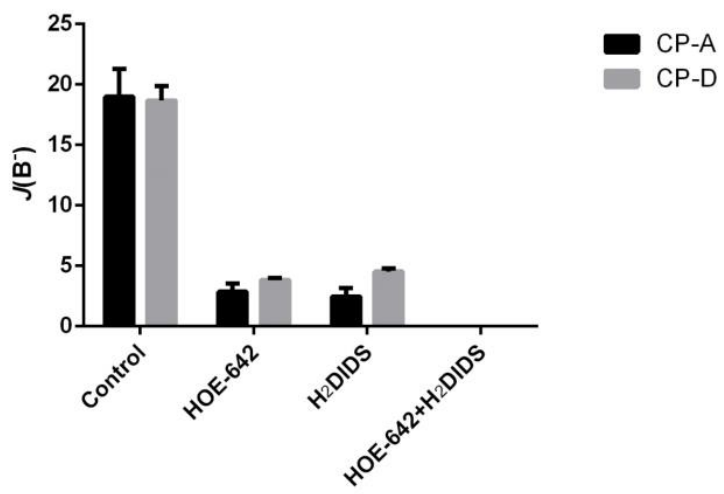

Figure 5. Investigation of NBC and NHE activities on EECs. (A) Representative $\mathrm{pH}_{\mathrm{i}}$ traces showing the effect of $\mathrm{H}_{2}$ DIDS $(500 \mu \mathrm{M})$ and HOE-642 $(50 \mu \mathrm{M})$ on the recovery from acidosis in $\mathrm{HCO}_{3}{ }^{-} / \mathrm{CO}_{2}$-buffered solution. CP-A cells were acid loaded twice. The first $\mathrm{NH}_{4} \mathrm{Cl}$ pulse was the control and the second was the test. $\mathrm{H}_{2} \mathrm{DIDS} / \mathrm{HOE}-642$ was added 1 min before the end of $\mathrm{NH}_{4} \mathrm{Cl}$ pulse and further 2 min after the pulse. (B) Summary data of the calculated NHE and NBC activities. The rate of acid recovery $\left[J\left(\mathrm{~B}^{-}\right)\right]$was calculated as described in Fig. 1. N.D. not detected. Data are presented as means \pm SE. $* P \leq 0.05$ vs. control; $n=15-25$.

Next we attempted to identify functionally active CBE. The activity of CBE was investigated by the $\mathrm{Cl}^{-}$removal technique in the presence and absence of $\mathrm{HCO}_{3}{ }^{-} / \mathrm{CO}_{2}$. In the absence of $\mathrm{HCO}_{3}{ }^{-}, \mathrm{Cl}^{-}$removal caused only a very low level and reversible alkalization. (Fig. 6A)

A

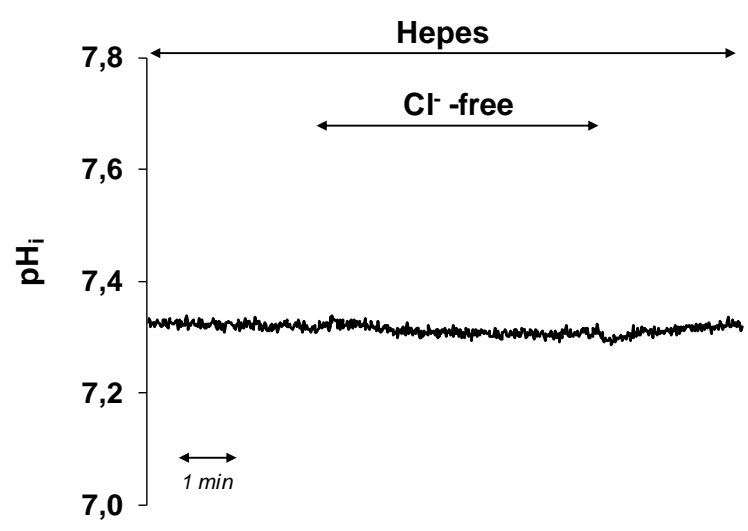

$\mathrm{B}$

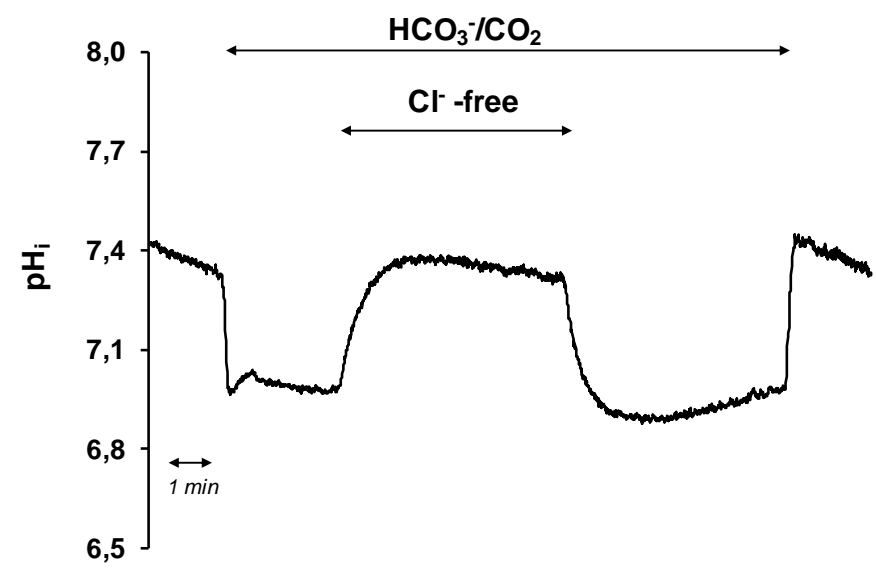

Figure 6. Investigation of CBE activity on EECs. The activity of $\mathrm{CBE}$ was investigated by the $\mathrm{Cl}^{-}$removal technique in the presence and absence of $\mathrm{HCO}_{3}{ }^{-} / \mathrm{CO}_{2}$. In standard HEPES-buffered solution (A), removal of $\mathrm{Cl}^{-}(5 \mathrm{~min})$ had no significant effect on $\mathrm{pH}_{\mathrm{i}}$. However, in standard $\mathrm{HCO}_{3}{ }^{-} / \mathrm{CO}_{2}$ solution $(\mathbf{B}), \mathrm{pH}_{\mathrm{i}}$ in the absence of $\mathrm{Cl}^{-}$significantly increased, indicating the presence of a functionally active $\mathrm{CBE}$ on $\mathrm{CP}-\mathrm{A}$ cells. 
However, removal of $\mathrm{Cl}^{-}$from the standard $\mathrm{HCO}_{3}{ }^{-} / \mathrm{CO}_{2}$ solution caused a marked and reversible alkalization suggesting the presence of $\mathrm{a} \mathrm{Cl}^{-}$dependent $\mathrm{HCO}_{3}{ }^{-}$efflux mechanism in $\mathrm{CP}-$ A cells. (Fig. 6B) In case of CP-D cells, a marked alkalization was also observed after the removal of external $\mathrm{Cl}^{-}$in the presence of $\mathrm{HCO}_{3}{ }^{-} / \mathrm{CO}_{2}$, suggesting that these cells also possess $\mathrm{CBE}$.

\subsubsection{Bile acids induces $\mathrm{Ca}^{2+}$ release via activation of IP3-mediated pathway}

Bile acids are known activators of many intracellular processes including $\mathrm{Ca}^{2+}$ signaling which is an important intracellular pathway. Therefore, in the next step we sought to identify the effect of BAC on intracellular $\left[\mathrm{Ca}^{2+}\right]_{\mathrm{i}}$. Since bile acids have ionophore properties, $(78,79)$ their effect was investigated both under neutral and acidic conditions. At 100 and $300 \mu \mathrm{M}$ concentrations, BAC had only a slight or no effect on $\left[\mathrm{Ca}^{2+}\right]_{\mathrm{i}}$ at neutral pH. (Fig. 7A and B) Acid by itself also had only a minimal effect on $\left[\mathrm{Ca}^{2+}\right]_{\mathrm{i}}$. (Fig. 7D) In contrast, at $500 \mu \mathrm{M}$ concentration bile acids induced a reversible increase in $\left[\mathrm{Ca}^{2+}\right]_{\mathrm{i}}$ at $\mathrm{pH} 7.5$, which was more pronounced at $\mathrm{pH}$ 5.5. (Fig. 7A and B). Next the source of $\mathrm{Ca}^{2+}$ release was identified. After removing $\mathrm{Ca}^{2+}$ from the extracellular solution administration of $500 \mu \mathrm{M}$ BAC, caused a slight increase in $\left[\mathrm{Ca}^{2+}\right]_{\mathrm{i}}$ strongly suggesting that $\mathrm{BAC}$ induces $\mathrm{Ca}^{2+}$ signaling from intracellular sources. (Fig. 7E). Therefore, in the next step we sought to identify the intracellular organellum from which the $\mathrm{Ca}^{2+}$ releases. Ryanodine (Ry) and inositol triphosphate $\left(\mathrm{IP}_{3}\right)$ receptors which mediate the release of $\mathrm{Ca}^{2+}$ from endoplasmic reticulum were blocked by their specific inhibitors, Ruthenium red (RR) and caffeine respectively. $10 \mu \mathrm{M} R \mathrm{R}$ had no effect on $\mathrm{BAC}$-induced $\mathrm{Ca}^{2+}$ release in $\mathrm{Ca}^{2+}$ free external solution. However, $20 \mathrm{mM}$ caffeine completely blocked the effect of $\mathrm{BAC}$ on $\mathrm{Ca}^{2+}$ signaling. Administration of $\mathrm{Gd}^{3+}$ a plasma membrane $\mathrm{Ca}^{2+}$ channel inhibitor decreased the effect of $500 \mu \mathrm{M} \mathrm{BAC}$ on $\left[\mathrm{Ca}^{2+}\right]_{\mathrm{i}}$ by $58.83 \pm 1.3 \%$ (Fig. 7E), indicating that beside the release of $\mathrm{Ca}^{2+}$ from intracellular sources, bile acids also induce the entry of extracellular $\mathrm{Ca}^{2+}$. 
A

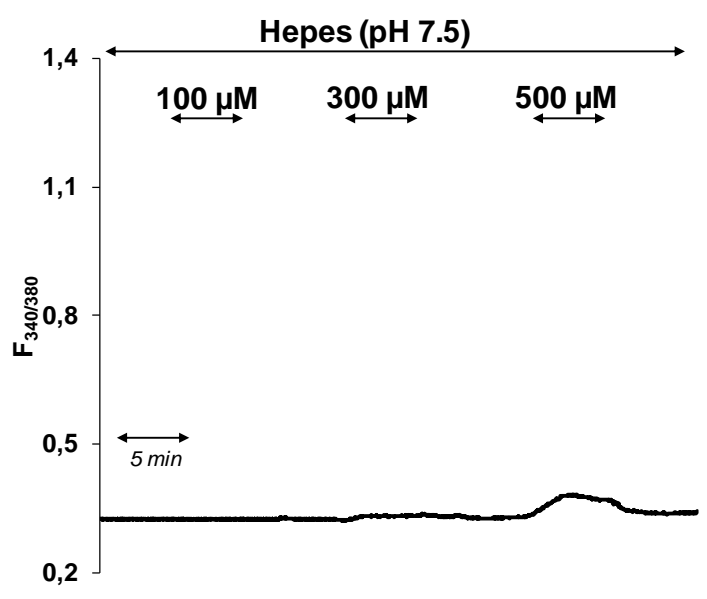

C

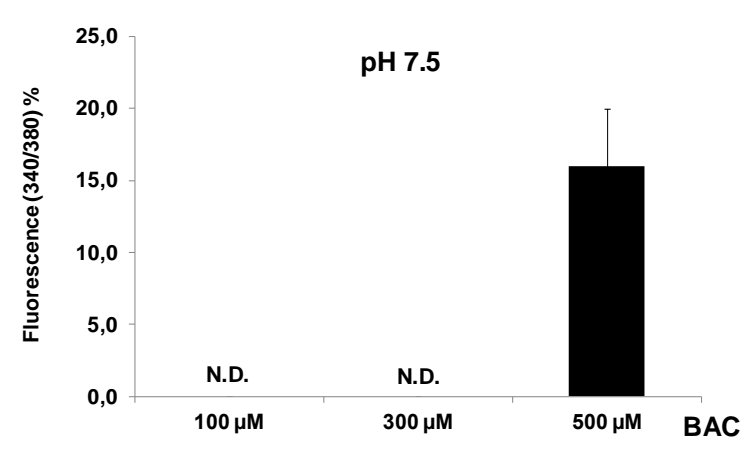

E

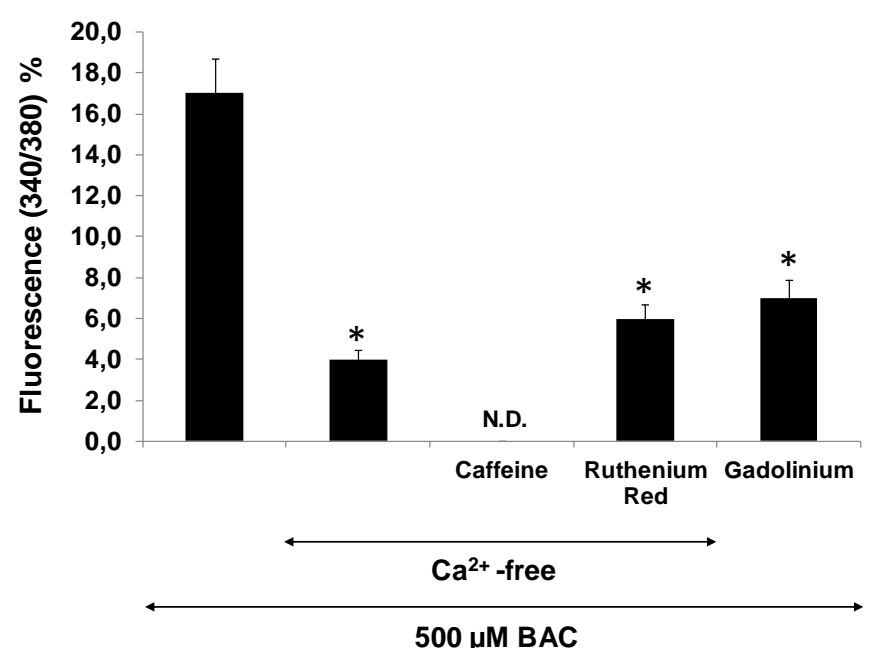

B

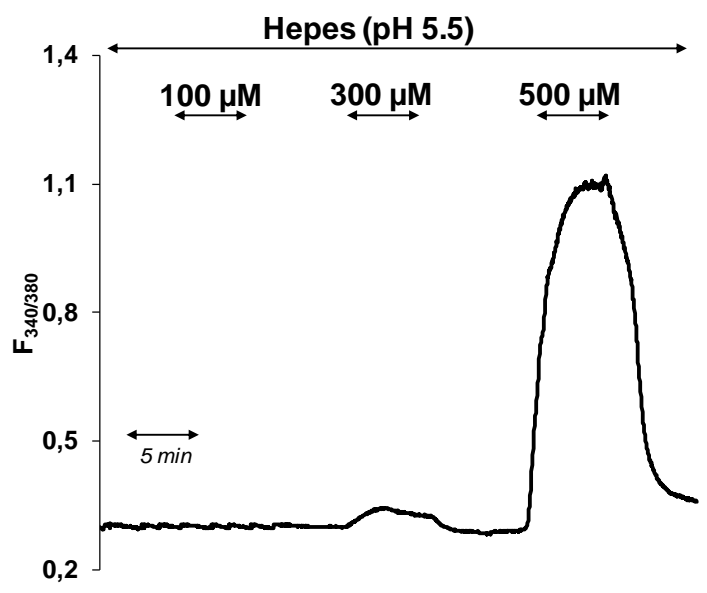

D

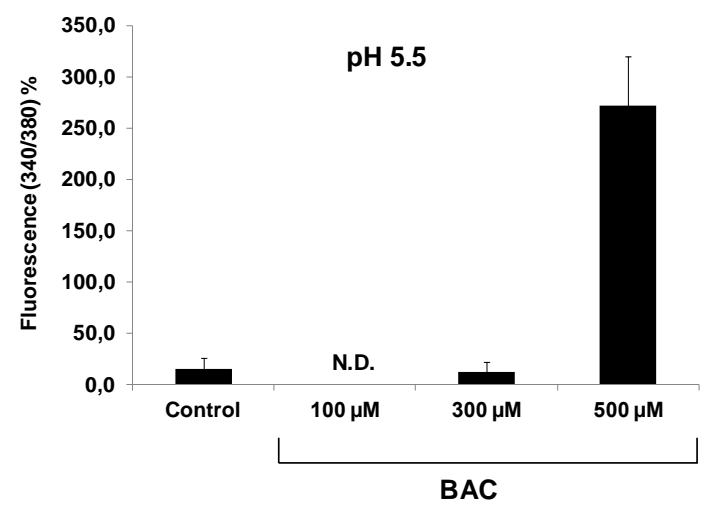

Figure 7. Effects of bile acids on $\left[\mathrm{Ca}^{2+}\right]_{i}$ in CP-A cells. Representative experimental traces showing the effect of a 100-, 300-, and 500- $\mu \mathrm{M}$ BAC at pH 7.5 (A) and pH $5.5(\mathbf{B})$ on $\left[\mathrm{Ca}^{2+}\right]_{\mathrm{i}}$. Summary data of the bile acid-induced $\left[\mathrm{Ca}^{2+}\right]_{\mathrm{i}}$ changes at $\mathrm{pH} 7.5(\mathbf{C})$ and $\mathrm{pH}$ 5.5 (D). Values are expressed as percent of basal $\left[\mathrm{Ca}^{2+}\right]_{i}$. (E) Effect of extracellular $\mathrm{Ca}^{2+}$ removal, caffeine $(20 \mathrm{mM}), \mathrm{RR}(10 \mu \mathrm{M})$ and $\mathrm{Gd}^{3+}(1$ $\mu \mathrm{M})$ on the rise in $\left[\mathrm{Ca}^{2+}\right]_{\mathrm{i}}$ induced by $500 \mu \mathrm{M}$ BAC. All experiments were performed in HEPES-buffered solution. Data are presented as means \pm SE. $* P \leq 0.05$ vs. $500 \mu \mathrm{M} \mathrm{BAC} ; n=$ 10-21. 


\subsubsection{Acute effects of bile acids on the activity of ion transporters in EECs}

Next, the acute effect of BAC on the activity of ion transporters was examined using the $\mathrm{NH}_{4} \mathrm{Cl}$ prepulse technique. Administration of $\mathrm{BAC}$ caused a dose-dependent decrease in the recovery from acidosis in Hepes-buffered solution (Fig. 8A and B), indicating that bile acids inhibit the activity of NHE in CP-A cells.

A

$\stackrel{\text { Hepes }}{\stackrel{100 \mu \mathrm{M} \mathrm{BAC}}{\hookrightarrow} \stackrel{300 \mu \mathrm{M} \mathrm{BAC}}{\longleftarrow} \underset{500 \mu \mathrm{M} \mathrm{BAC}}{\longleftarrow}}$

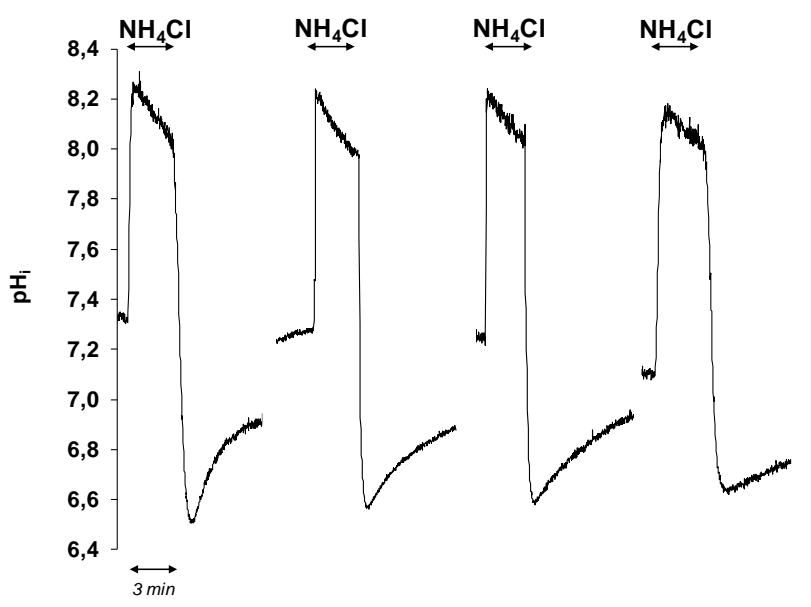

$\mathrm{C}$

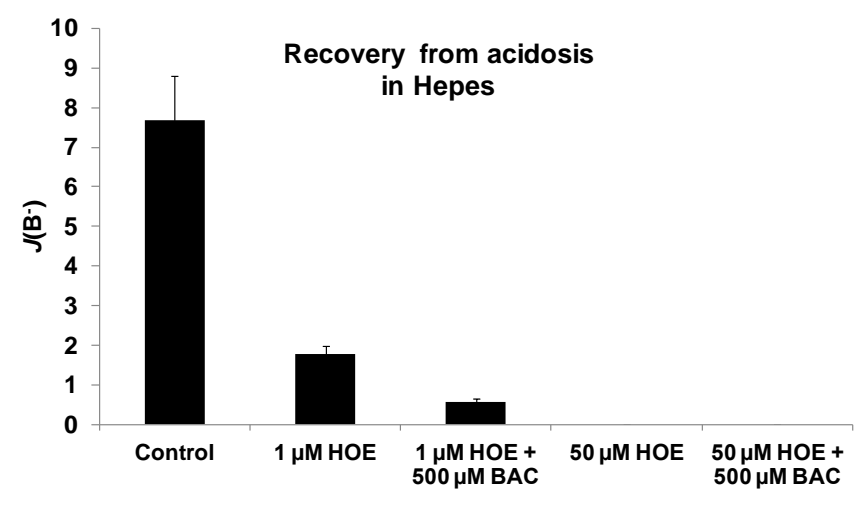

B

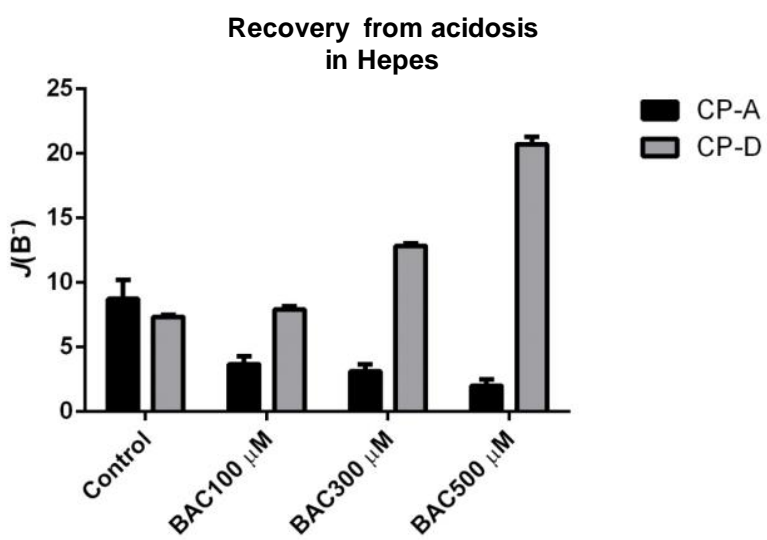

Figure 8. Effects of bile acids on NHEs in EECs. (A) representative $\mathrm{pH}_{\mathrm{i}}$ traces show the effect of a 100-, 300-, and 500- $\mu \mathrm{M}$ BAC in HEPES-buffered solution on the CP-A cell line. Cells were treated with bile acids 3 min before the pulse started, during the $\mathrm{NH}_{4} \mathrm{Cl}$ pulse, and $3 \mathrm{~min}$ after the pulse. (B) Summary of the calculated NHE activity in CP-A and CP-D cells. (C) Summary of the effect of $500 \mu \mathrm{M}$ BAC on the activities of different NHE isoforms in $\mathrm{CP}-\mathrm{A}$ cells in the presence of 1 and $50 \mu \mathrm{M}$ HOE-642. Data are presented as means \pm SE. $* P \leq 0.05$ vs. control; $n=15-25$.

In order to determine which NHE isoform is involved in the inhibitory effect of bile acids, the effect of BAC was tested in the presence of the isoform-specific NHE inhibitor, HOE-642. 1 $\mu \mathrm{M}$ HOE-642 decreased the recovery from acidosis from $7.68 \pm 1.11$ to $1.78 \pm 0.2$. Administration 
of $500 \mu \mathrm{M}$ BAC, in the continuous presence of HOE-642, further decreased the acid recovery to $0.56 \pm 0.09$ (Fig. 8C) Since $500 \mu \mathrm{M}$ BAC inhibited acid recovery by $77.15 \pm 3.2 \%$, and nearly $77 \%$ of the total NHE activity is due to NHE1, these results indicate that BAC remarkably inhibits NHE1, however it also blocks NHE2 activity.

A

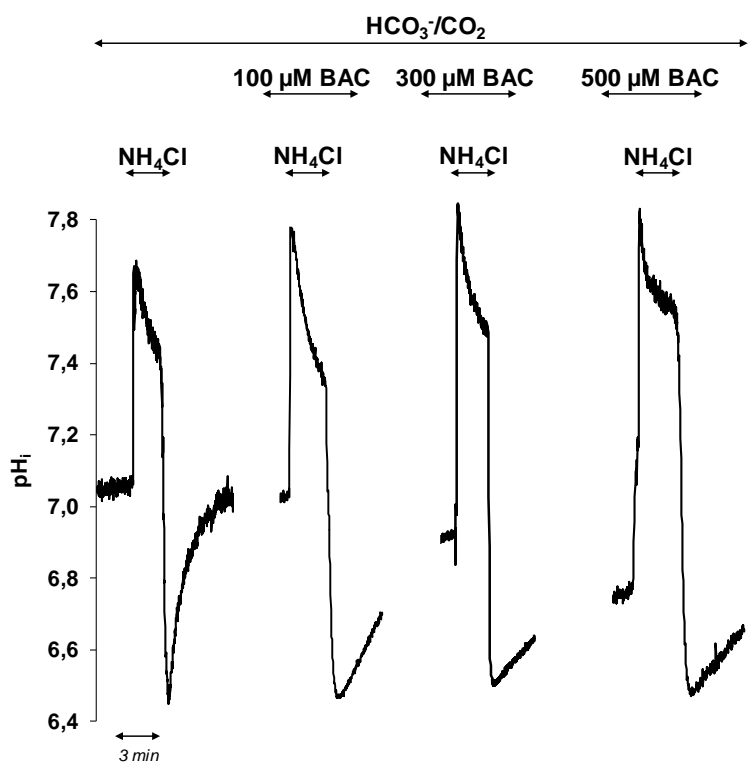

$\mathrm{C}$

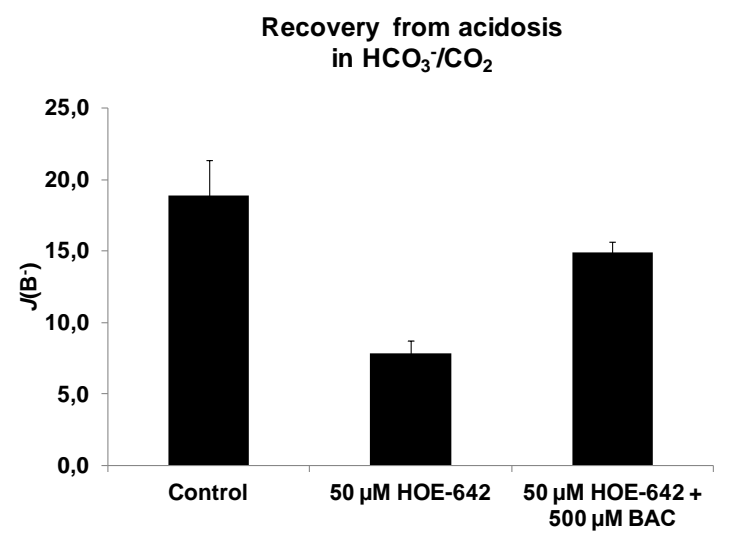

B

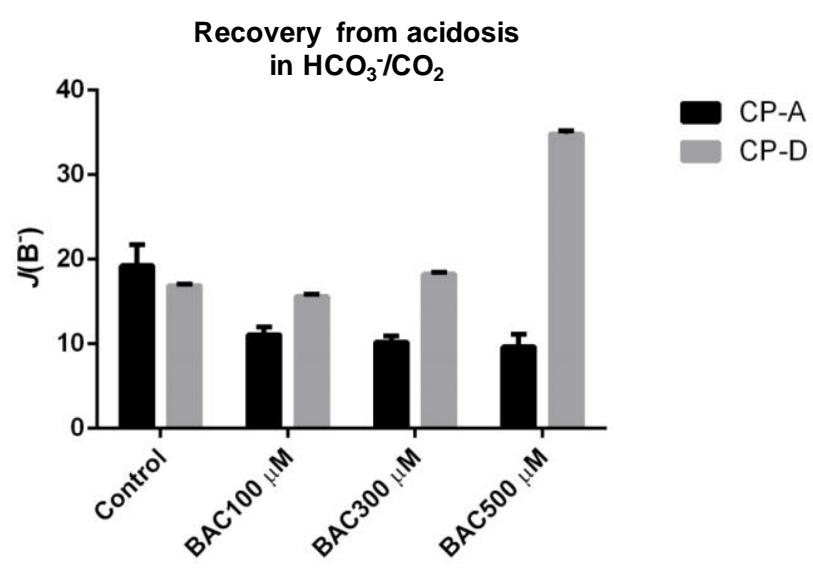

$\mathrm{D}$

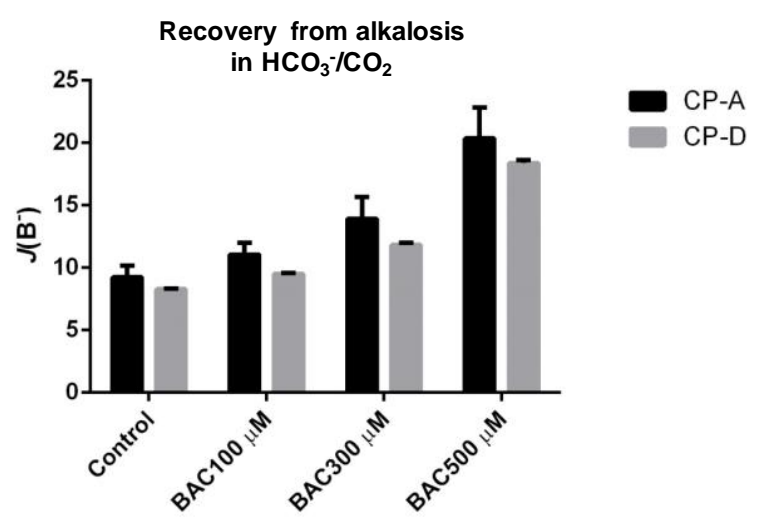

Figure 9. Effects of bile acids on NBC and CBE in EECs. (A) Representative $\mathrm{pH}_{\mathrm{i}}$ traces show the effect of 100-, 300-, and 500- $\mu \mathrm{M} \mathrm{BAC}$ in $\mathrm{HCO}_{3}{ }^{-} / \mathrm{CO}_{2}$-buffered solution on the $\mathrm{CP}$-A cell line. Cells were treated with bile acids 3 min before the pulse started, during the $\mathrm{NH}_{4} \mathrm{Cl}$ pulse and 3 min after the pulse. (B) Summary of the calculated NHE and NBC activities in CP-A and CP-D cells. The rate of acid recovery $\left[J\left(\mathrm{~B}^{-}\right)\right]$was calculated as described in Fig. 1. (C) summary data of the calculated rates of $\mathrm{pH}_{\mathrm{i}}$ recovery from acid load in $\mathrm{HCO}_{3}{ }^{-} / \mathrm{CO}_{2}$-buffered solution in CP-A cells. The effect of bile acids on NBC activity was evaluated in the presence of $50 \mu \mathrm{M}$ HOE-642. The rate of acid 
recovery $\left[J\left(\mathrm{~B}^{-}\right)\right]$was calculated as described in Fig. 1. (D) summary of the calculated CBE activity in CP-A and CP$\mathrm{D}$ cells. The rate of alkali recovery $\left[-J\left(\mathrm{~B}^{-}\right)\right]$was calculated from the $\Delta \mathrm{pH} / \Delta t$ obtained by linear regression analysis of $\mathrm{pH}_{\mathrm{i}}$ measurements made over the first $30 \mathrm{~s}$ of recovery from the highest $\mathrm{pH}_{\mathrm{i}}$ level (start point $\mathrm{pH}_{\mathrm{i}}$ ). The buffering capacity at the start point $\mathrm{pH}_{\mathrm{i}}$ was used for the calculation of $J\left(\mathrm{~B}^{-}\right)$. Data are presented as means $\pm \mathrm{SE} . * P \leq 0.05$ vs. control; $n=15-25$.

Since $\mathrm{Ca}^{2+}$ plays an essential role in the function of several intracellular processes, we examined whether the observed inhibitory/stimulatory effect of BAC on ion transporters is mediated by $\mathrm{Ca}^{2+}$. Pretreatment of the cells with the $\mathrm{Ca}^{2+}$ chelator BAPTA-AM, a significant decrease was obtained both in the inhibitory and stimulatory effects of $500 \mu \mathrm{M}$ BAC on the ion transporters, indicating that the effects of bile acids on ion transporters are $\mathrm{Ca}^{2+}$-dependent (data not shown).

\subsubsection{Chronic exposure of EECs to bile acids}

Next, the long-term effects of bile acid treatment on the expression of ion transporters were assessed. CP-A and CP-D cells were grown to 70-80\% confluency and treated with 100 and 500 $\mu \mathrm{M}$ BAC at pH 7.5 and pH 5.5 as described in Material and Methods. 7-days treatment with BAC significantly increased the expression of NHE1, NHE2, NBC and CBE isoform Slc26a6 compared to non-treated control cells at pH 7.5 in CP-A cells. (Fig. 10A) The expression of these ion transporters also increased in CP-D cells, however, significant changes were only detected in the case of NHE1 and NBC. (Fig. 10B) We have also performed these experiments under acidic (pH 5.5) conditions. In CP-A cells, at acidic $\mathrm{pH}$ alone or in combination with bile acids the expression levels of ion transporters did not change significantly (Fig. 10C) and a decreased cell number was observed compared to the control groups. In contrast, CP-D cells displayed a significant increase in NHE1 levels after bile acid treatment at pH 5.5. (Fig. 10D) We have also shown that the enhanced mRNA levels of NHE1 were associated with significantly increased protein expression. (Fig. 10E) The Slc26a6 transporter expression also increased in CP-A cells at neutral pH (data not shown). These data are in accordance with our PCR results. However, in the case of NHE2 and NBC, there were no significant difference in the protein expression, between the control and the bile acid-treated group at neutral $\mathrm{pH}$ (data not shown). 
A

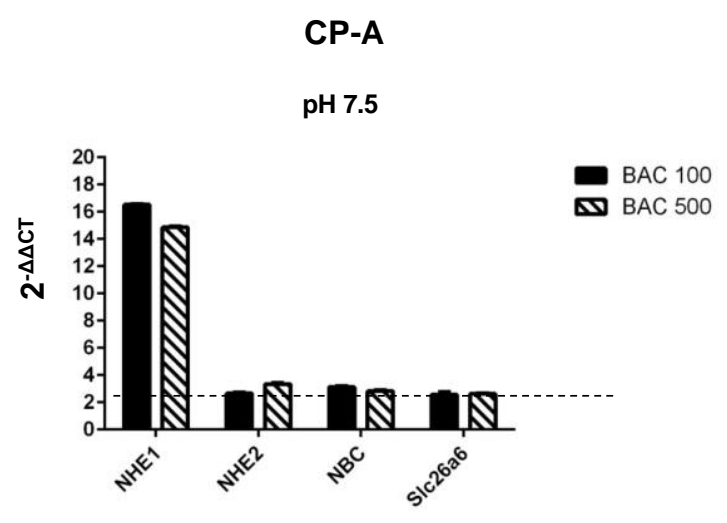

C

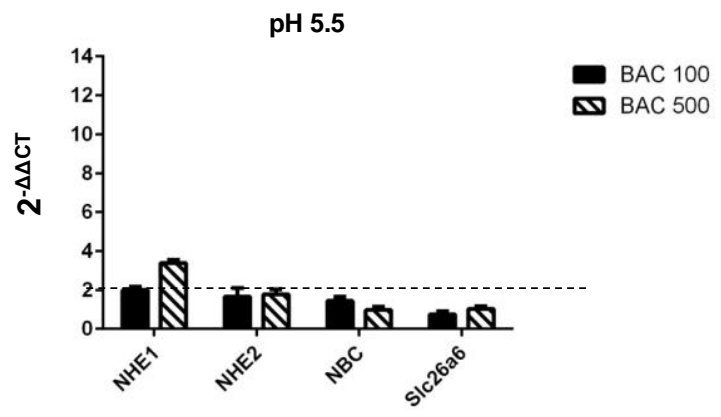

B
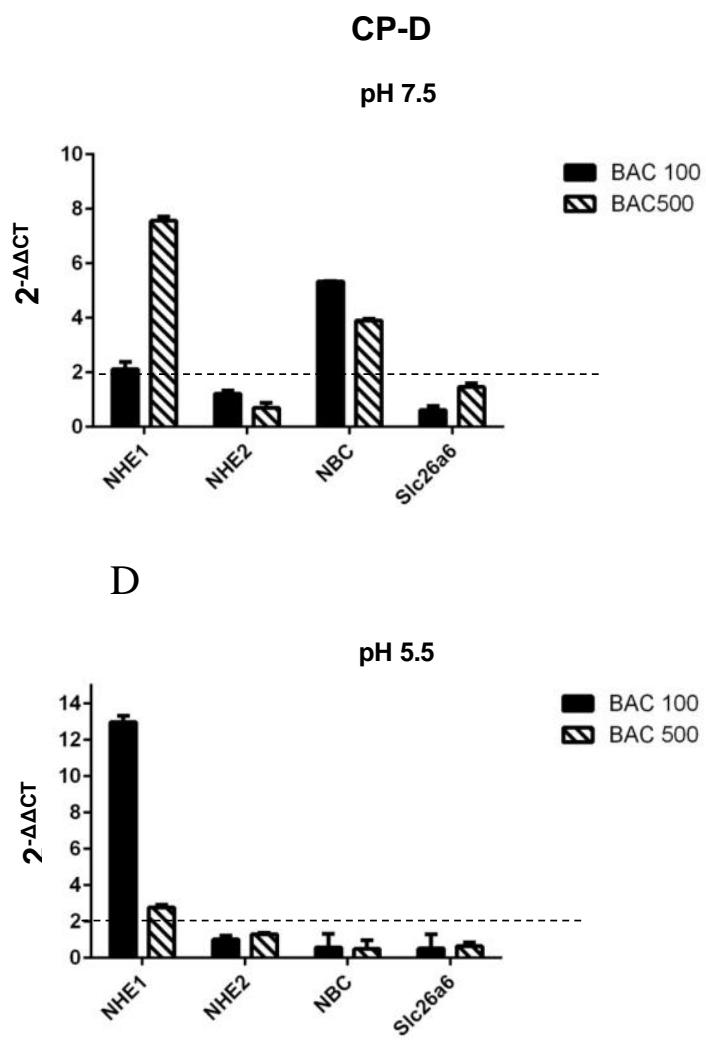

E

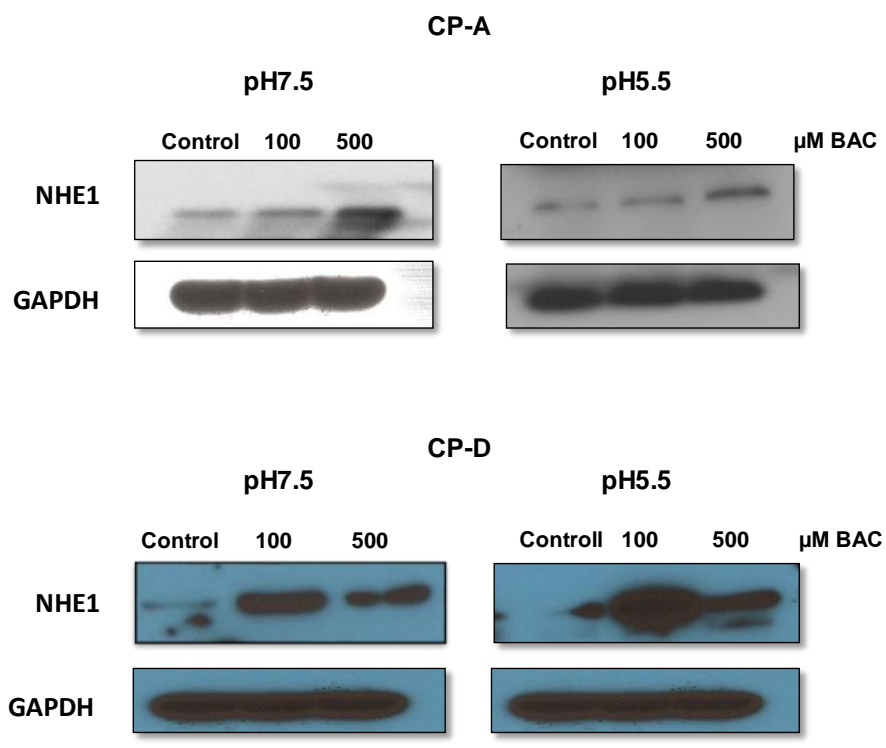

Figure 10. Expression of ion transporters in Barrett's cell lines. CP-A and CP-D cells were treated with different bile acids for 7 days at $\mathrm{pH} 7.5$ (A and $\mathbf{B}$ ) and 5.5 (C and D) and the relative mRNA expressions of NHE1, NHE2, NBC, and Slc26a6 were investigated by real-time $\mathrm{PCR}$. Data are presented as means $\pm \mathrm{SE}$. (E) Western blot analysis for NHE1 protein expression after $100-$ and $500-\mu \mathrm{M}$ bile acid treatments 
Finally, we assessed the mRNA expression pattern of ion transporters in human derived tissue. 14 pairs of normal squamous and BE biopsy samples obtained from patients with known BE was investigated. (Fig. 11A-C)

A
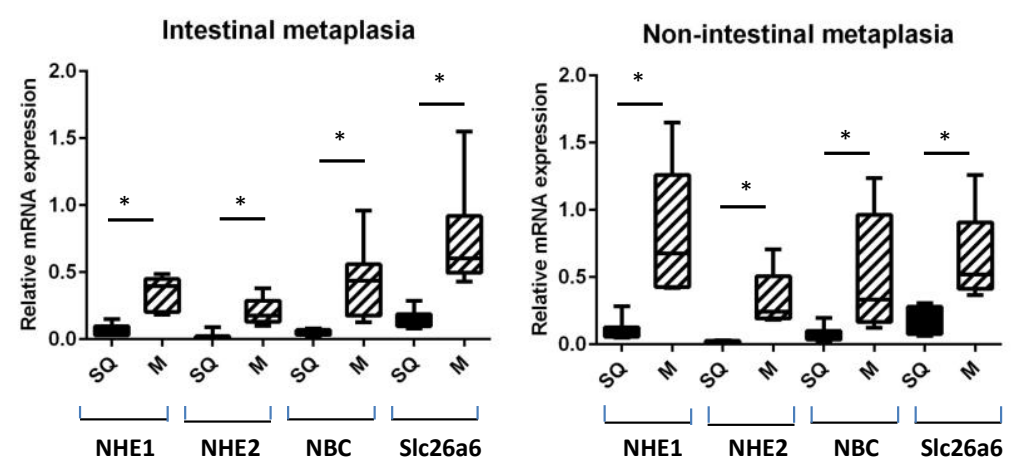

C

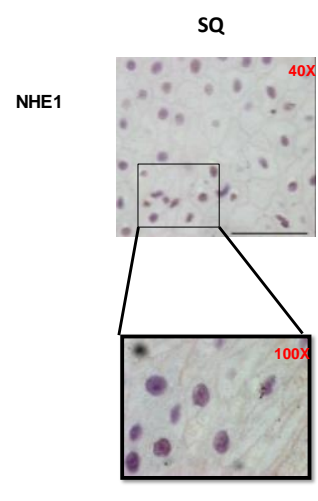

SQ

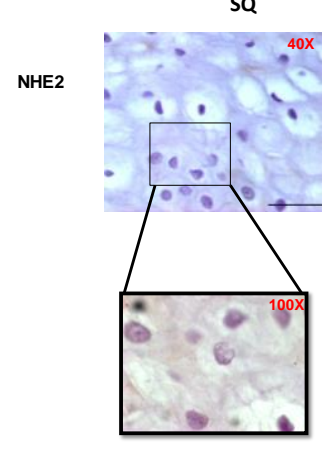

B

Figure 11. Expression of ion transporters in human esophageal biopsy samples. Box plots show the relative expression of NHE1, NHE2, NBC, and Slc26a6 in biopsy samples derived from intestinal (A) and non-intestinal (B) metaplasia. Median values are shown as a horizontal black bar within each box. $* P \leq 0.05$ vs. normal SE; $n=7$. (C) representative pictures show IHC staining of NHE1 and NHE2 in normal esophageal squamous mucosa and intestinal metaplastic tissue specimens. Isotype negative control (NC) was also included to assess nonspecific staining. SQ, squamous mucosa; M, metaplasia. Arrows pointing toward NHE- 1 and NHE-2 staining. Scale bar $=50 \mu \mathrm{m}$.

Using qPCR, increased mRNA expressions of NHE1, NHE2, NBC and Slc26a6 in BE were found both in intestinal (Fig. 11A) and non-intestinal (Fig. 11B) metaplasia compared to 
normal epithelium. The protein expression of NHE1 and NHE2 were also investigated by IHC. Biopsy samples from both intestinal and non-intestinal metaplastic columnar mucosa displayed strong staining against NHE1 and NHE2 antibodies in contrast to normal SE. (Fig. 11C)

\subsection{Role of autophagy in the pathogenesis of GERD and BE}

\subsubsection{Effects of pharmacologic inhibition of autophagy following acidic stress on ROS production}

First, the role of autophagy in cellular response after acidic stress was evaluated. STR, CPA, CP-D and OE19 cell lines were exposed to acidic challenge at $\mathrm{pH}=3.5$ followed by treatment with $50 \mu \mathrm{M}$ CQ or vehicle control. CQ is a specific inhibitor of autophagy which acts through blocking the fusion of autophagic vacuoles (AVs) with lysosomes. Six hours post-exposure cells were stained with DCF or Cyto-ID to determine intracellular ROS levels and autophagic responses, respectively. DCF and Cyto-ID autophagy fluorescence were quantified by flow cytometry. Flow cytometry observations were confirmed by confocal microscopy on STR cells (Fig. 12A and C) Unstained cells in additional plates were maintained until 24 hours post acid exposure, at which an assay for cell viability was performed.

In both STR and CP-A cells, acid treatment significantly increased ROS levels at 6 hours post exposure (Figure 12A and B). CQ alone had a mixed impact on cellular ROS levels-increasing them in STR but not CP-A cells. However, CQ in combination with acid stress induced an additional significant increase in ROS levels in both STR and CP-A cells compared to cells which were exposed to acid only (Figure12A and B). Autophagy levels were similarly responsive to these treatments in STR and CP-A cells. Cyto-ID autophagy levels were increased by all three conditions: acid exposure alone, CQ, as well as the combined treatments. The increase observed with CQ is due to the accumulation of blocked AVs (Figure 12C and D).

In both CP-D and OE19 cells, these cellular responses were different. As with the nondysplastic cells, the acid treatment led to a significantly increased ROS levels at 6 hours post exposure in these cell lines (Figure 12B). CQ alone had no significant effect on cellular ROS levels. However, when CQ was combined with acid stress, there was no additional increase in ROS levels experienced by either the CP-D or OE19 cells compared to cells which were exposed to acid alone (Figure 12B). 

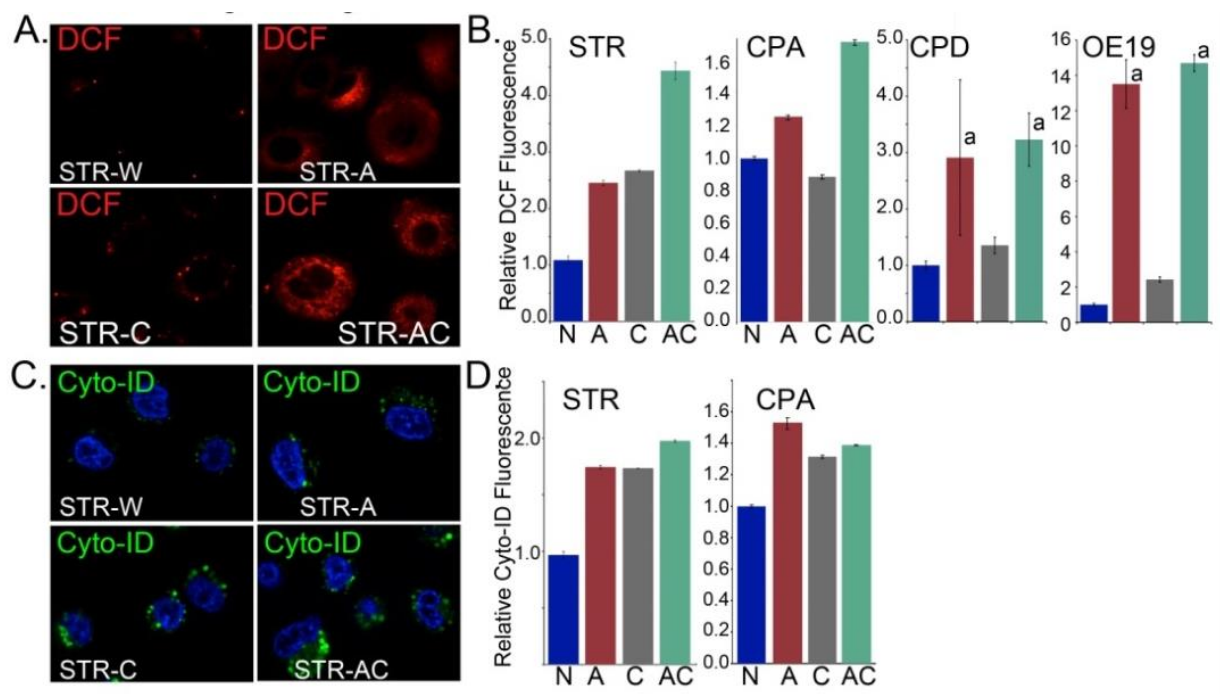

Figure 12. Effects of autophagy inhibition on intracellular ROS and AV formation after GERD-like acid exposure. (A) Relative intracellular ROS levels are determined by DCF fluorescence in STR cells at $6 \mathrm{~h}$ post treatment; imaged by confocal microscopy. W: control nonacidic media; A: acid [pH3.5] pulsed; C: CQ treated; AC: acid pulsed followed by CQ treatment. (B) Summary of DCF fluorescence quantified by flow cytometry in normal (STR) and BE (non-dysplastic CP-A) cell lines treated as before and measured at $6 \mathrm{~h}$ post treatment; $\mathrm{n}=6$ experiments for each. Significance testing was by one-way ANOVA followed by Tukey's multiple comparison test; a: significantly differs from control and CQ treated cells; $b$ : significantly differs from acid and CQ treated cells by one-way ANOVA and Tukey's multiple comparison test; $P \leq 0.05$. (C) Relative autophagy induction $6 \mathrm{~h}$ post treatment with acid or/and CQ as determined by Cyto-ID fluorescence in STR cells and imaged by confocal microscopy. (D) Summary of CytoID fluorescence and relative autophagy induction quantified by flow cytometry in representative normal (STR), BE (non-dysplastic/CP-A and dysplastic/ CP-D) and EAC (OE19) cell lines treated as before and measured at $6 \mathrm{~h}$ posttreatment; $\mathrm{n}=6$ experiments for each. a: significantly differs from control treated cells by one-way ANOVA and Tukey's multiple comparison test; $P \leq 0.010 .001$. b: significantly differs from acid and CQ treated cells by one-way ANOVA and Tukey's multiple comparison test; $P \leq 0.05$.

Similarly, the quantification of the autophagic response of CP-D cells to acidic stress failed to show any change in Cyto-ID fluorescent signal after any treatment (Figure 13A), including the CQ treatment alone. Furthermore, in OE19 cells the exposure to acid significantly reduced this relative fluorescence signal (Figure 13B). As these observations ran contrary to our expectations, especially with respect to CQ treatment, we were concerned that there was a problem with the Cyto-ID fluorescence as a measure of autophagy responses. We therefore examined the Cyto-ID fluorescent by confocal microscopy in OE19 cells after these same treatments and in parallel treated LC3-GFP labeled OE19 cells as a second measure of the autophagic response following the same experimental protocol. LC3 is the most widely used marker for autophagosome and the examination of GFP-labeled LC3 localization is a very simple and highly sensitive method to measure autophagic activity in living cells. (6) Unexpectedly, there was a significant difference between the two methodologies. In untreated OE19 cells, Cyto-ID fluoresces brightly in 
cytoplasmic vesicles, while LC3-GFP does not similarly collect (Figure 13C and D). Moreover, while LC3-GFP vesicles were increased weakly by acid treatment and strongly after CQ treatment, Cyto-ID fluorescence pattern recapitulated that measured by flow cytometry, with diminished signal in acid-treated cells (Figure 13C and D).

A.

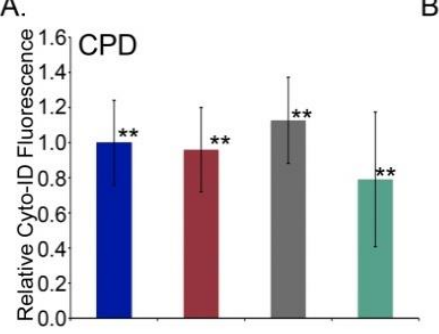

B.

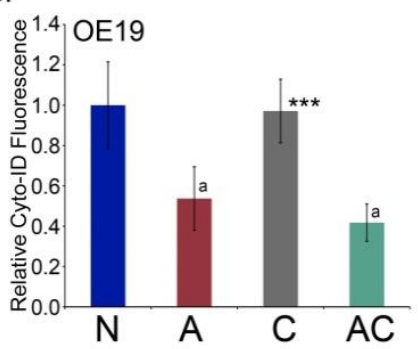

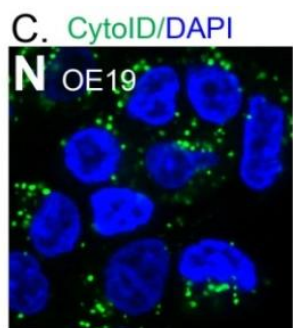

CytolD/DAPI

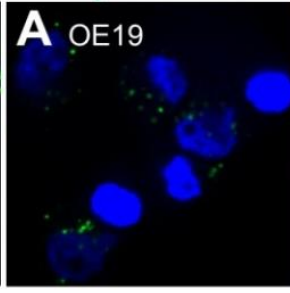

CytoID/DAPI

CytoID/DAPI

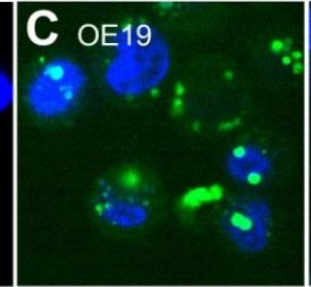

\section{AC OE19}

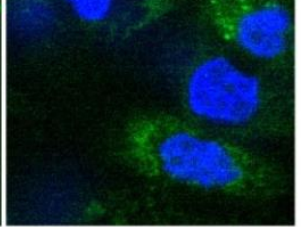

D.
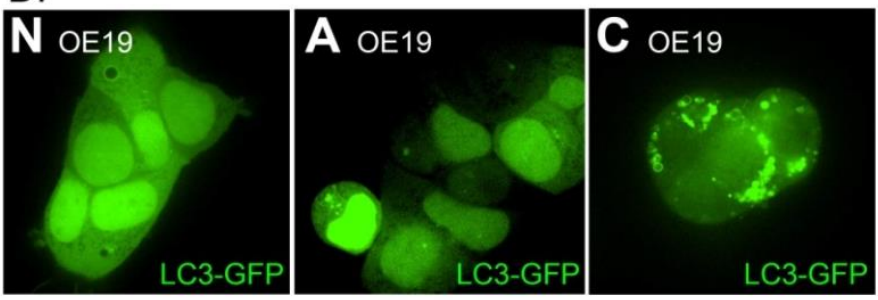

AC OE19

Figure 13. Cyto-ID fluorescence does not correlate with LC3-GFP vesicle levels in OE19 cells. (A) and (B) Summary of Cyto-ID fluorescence quantified by flow cytometry in representative dysplastic BE (CP-D) and EAC (OE19) cell lines treated as before and measured at 6 hours post-treatment. $\mathrm{N}=$ control nonacidic media; $\mathrm{A}=\mathrm{acid}[\mathrm{pH}$ 3.5] pulsed; $C=C Q$ treated; $A C=$ acid pulsed followed by $C Q$ treatment. Significance testing was by one-way ANOVA followed by Tukey's multiple comparison test; $\mathrm{n}=6$ experiments for each. ${ }^{* *}$ not significantly different by one-way ANOVA $\mathrm{p}=0.2635 . \mathrm{a}=$ significantly differs from control and CQ treated cells; adjusted $P \leq 0011 . * * *=$ not significantly differs from control treated cells; adjusted $\mathrm{p}=0.99$. (C) Relative autophagy induction 6 hours post treatment with acid or/and CQ as determined by Cyto-ID fluorescence in STR cells and imaged by confocal microscopy. $\mathrm{N}=$ control nonacidic media; $\mathrm{A}=\mathrm{acid}$ [pH 3.5] pulsed; $\mathrm{C}=\mathrm{CQ}$ treated; $\mathrm{AC}=$ acid pulsed followed by $\mathrm{CQ}$ treatment. (D) Cells imaged by epifluorescence microscopy to visualize fluorescent AV puncta in LC3-GFP expressing OE19 cells after acid and/or CQ treatment. 


\subsubsection{Acidic challenge diminishes cell viability after pharmacologic inhibition of autophagy by CQ}

In a final study, we were interested whether the autophagic flux following acid treatment gives any functional benefit to the cells demonstrated by the survival advantage provided by an autophagic response. 7AAD staining was used as a highly quantitative flow cytometry approach to assess cell death. 7AAD+ dead cells were quantified 24 hours after treatment with acid, CQ, or the combination of acid and CQ, in all four cell. Cell death after acid treatment was increased in three of four cell lines (STR, CP-A, and CP-D), but this was most significant for CP-D cells (Figure 14A, B, and C). STR cells were uniquely sensitive to CQ, with a nearly 5-fold increase in 7AAD+ dead cells after 24 hours of treatment. Most important, for all cell lines examined, the combination of acidic stress and CQ treatment led to a very significant increase in 7AAD+ dead cells at 24 hours (Figure 14A, B, C, and D). In STR, CP-A, and OE19 cells, the combination of acidic stress and inhibition of autophagy synergized and led to greater level of cell death than the sum of the individual treatments (Figure 14A, B, and D).
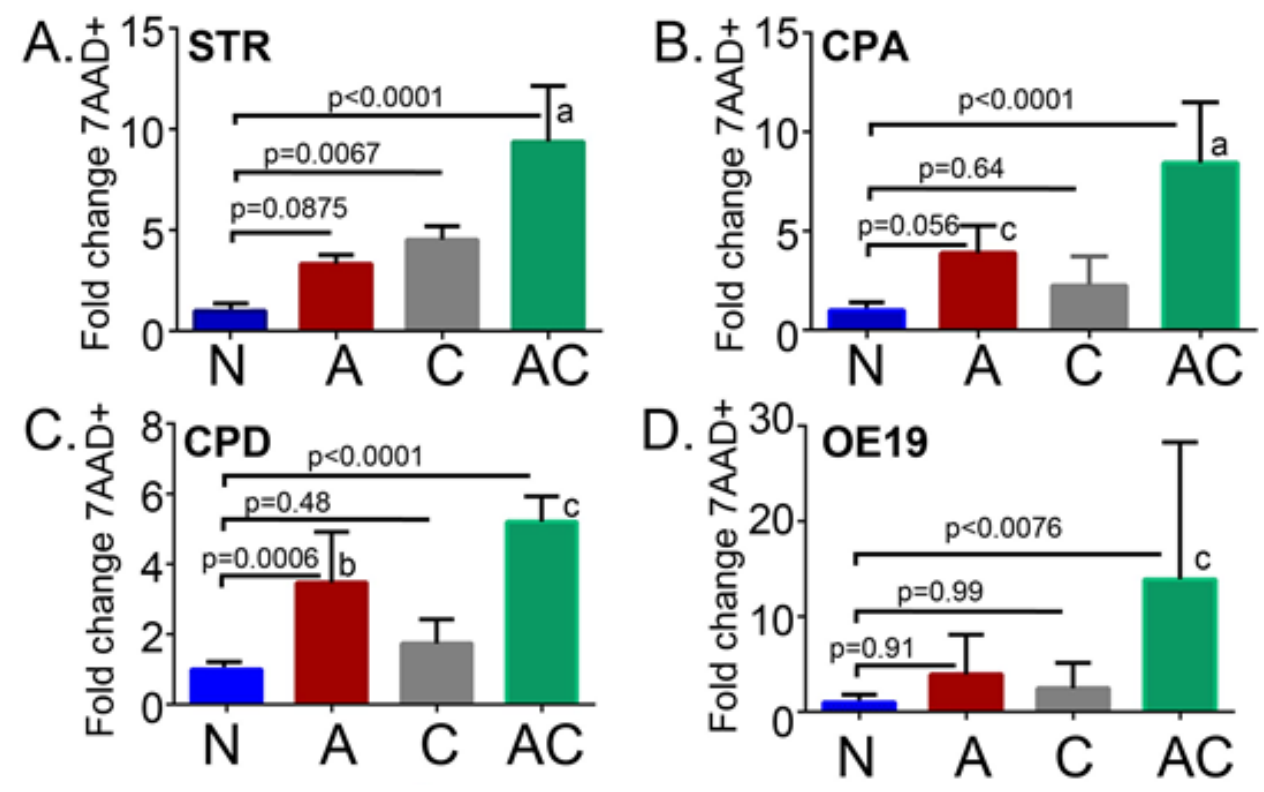

Figure 14. Inhibition of autophagy increases cell death after GERD-like acid exposure. Flow cytometric quantitation of 7-amino-actinomycinD (7AAD) cell staining at $24 \mathrm{~h}$ in (A) STR cells, (B) CP-A cells, (C) CP-D cells, and (D) OE19 cells. 7AAD+ cells are expressed as fold-increased over non- acid treated control cells. N: control nonacidic media; A: acid pulsed [pH3.5]; C: CQ treated; AC: acid pulsed followed by CQ treatment; $\mathrm{n} 1 / 46$ experiments for each. Significance testing was by one-way ANOVA followed by Tukey's multiple comparison test; $\mathrm{P}$-values adjusted for multiple comparisons are reported. a: significantly differs from acid and CQ treatments, $\mathrm{P}=$ 0.0018. b: significantly differs from CQ treatments, $\mathrm{P}$ 0.015. c: significantly differs from acid and CQ treatments, $\mathrm{P}=$ 0.028 . 


\subsection{Modeling esophagitis using 3D organotypic culture system}

\subsubsection{The organotypic culture environment sustains immune cells and permits their normal activation when stimulated by cytokines}

OTC systems allow for the co-culture of immortalized normal human esophageal epithelial cells together with primary human fibroblasts in 3D tissue reconstructions that recapitulates normal esophageal epithelial morphology and differentiation (Figure 15 A and B). (64) In order to develop a human in vitro model of esophageal inflammatory conditions human PBMCs were included in the collagen/Matrigel extracellular matrix at the initiation of the culture, prior to the establishment of the epithelial cell layer (Figure 15A and C). To insure immune cell viability during the 14 day culture period, IL-2 was added to the cell culture media. PBMCs remained viable throughout the culture period, as indicated by $\mathrm{CD} 45^{+}$cells in the collagen matrix/stromal compartment of the OTC cultures (Figure 15C). Interestingly, no spontaneous activation of immune cells was observed, demonstrated by the absence of lymphocyte proliferation (Figure 15D) and cytokine production (data not shown), despite the fact that the PBMCs, fibroblasts and epithelial cells were derived from different donor source.

In order to induce a robust $\mathrm{T}_{\mathrm{H}} 1$ acute inflammatory response, we elected to include the potent pro-inflammatory cytokines IL-7 and IL-15 in the culture media. IL-7 and IL-15 are both tissue-derived cytokines most abundantly expressed by stromal and epithelial cells, including keratinocytes. (80-83) Both cytokines are potent inducers of $\mathrm{T}_{\mathrm{H}} 1$ acute inflammatory cytokines including interferon- $\gamma$ in T-cells and monocytes, and both have profound effects on T-cell survival and proliferation, including helper (CD4+) and effector (CD8+) T-cells and NK-cells, during all phases of T-cell development. $(83,84)$ Unlike IL-2 alone, these three cytokines together supported the induction of an acute inflammatory response in the OTC-PBMC co-culture environment. 


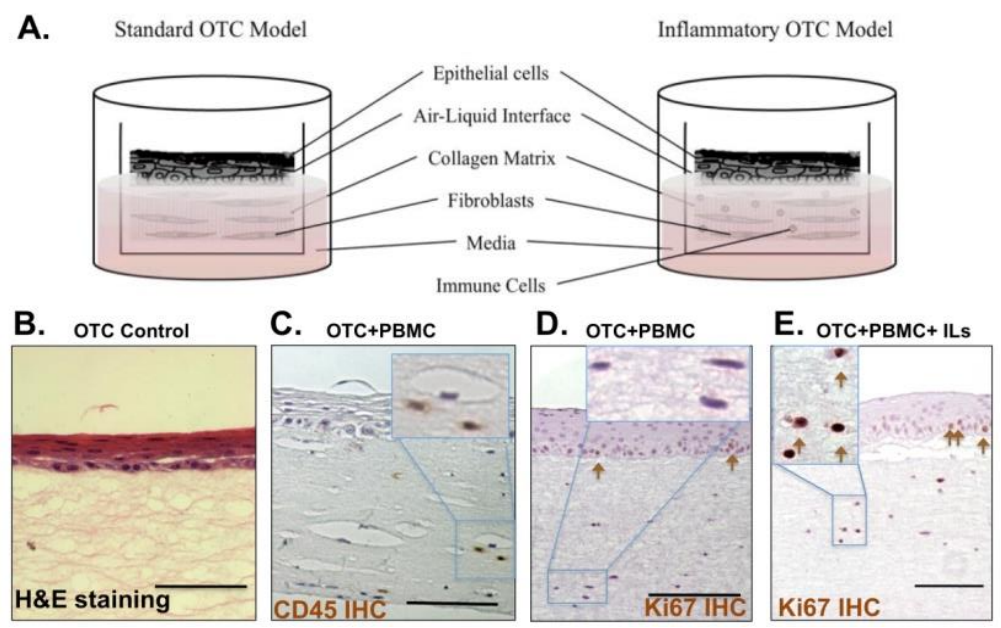

Figure 15. Modeling esophageal inflammation. (A) Illustration of the standard OTC method (left), as well as the modification introduced by incorporating PBMCs into the collagen matrix to model inflammation (right). (B) Representative pictures show H\&E staining of normal human esophageal keratinocytes grown under standard OTC conditions. (C) CD45 IHC staining of an OTC culture with human PBMCs and IL-2 added. CD45 ${ }^{+}$staining indicates the presence of immune cells in the collagen matrix. Inset: higher power magnification of CD45 cells. (D) IHC staining for the cell proliferation marker Ki-67 in an OTC+PBMC culture. Ki-67 ${ }^{+}$cells noted in the epithelium (Brown arrows) but not in stromal cells. Inset: higher power magnification of Ki-67 negative stromal cells. (E) IHC staining for the cell proliferation marker $\mathrm{Ki}-67$ in an OTC+PBMC+IL culture. Ki- $67^{+}$cells noted in both the epithelium and stromal cells (Brown arrows). Inset: higher power magnification of Ki- $67^{+}$stromal cells. Scale bar represent $50 \mu \mathrm{m}$

The addition of IL-7 and IL-15 induced a very significant increase in the number of CD45 immune cells in the OTC-PBMC cultures (Figure 16A, right panel). This effect was not observed when PBMCs were co-cultured with only IL-2 (Figure 16A, center panel). While some of the increased numbers of $\mathrm{CD} 45^{+}$cells might be due to increased cell survival with IL-7 and IL-15, a portion of the increase was due to immune cell proliferation, as indicated by the $\mathrm{Ki}^{+} 7^{+}$stromal cells in the OTC+PBMC+IL cultures (Figure 15E) but not the OTC+PBMC control (Figure 15D). In addition to the increased numbers of PBMCs, there was a noticeable infiltration of lymphocytes into the OTC epithelium, characteristic of esophagitis, with the addition of the pro-inflammatory interleukins (Figure 16B). A general characteristic of immune cell activation is the increased production of cytokines. We were unable to directly detect the canonical $\mathrm{T}_{\mathrm{H}} 1$ cytokine IFN- $\gamma$ in cell culture media from the OTC+PBMC+IL cultures despite multiple attempts (data not shown). We suspect this is due to the dense OTC collagen matrix in which the PBMCs are maintained in, 
as we readily detect increased IFN- $\gamma$ levels in the cell culture media when PBMCs are cultured in a soft Matrigel matrix and exposed to the same $\mathrm{T}_{\mathrm{H}} 1$ pro-inflammatory cocktail IL-2, -7 , and -15 (data not shown). As a surrogate marker, we examined the overlying epithelium in the OTC cultures for expression of interferon regulatory factor 1 (IRF-1), a member of the interferon regulatory transcription factor family and a well-known target gene of IFN- $\gamma$ signaling. (85) We observed a highly significant increase in the levels of IRF-1 mRNA and protein detected in the epithelium from the OTC+PBMC+IL cultures (Figure 16C and D). However, IRF-1 mRNA and protein were not increased in the epithelium from control cultures treated either with the $\mathrm{T}_{\mathrm{H}} 1$ promoting interleukins or with PBMCs alone (Figure 16C), indicating this response was specific to the OTC+PBMC+IL cultures. Together these findings establish that human PBMCs incorporated into the OTC culture environment remain viable and can proliferate and produce IFN$\gamma$ when provoked by pro-inflammatory cytokines.

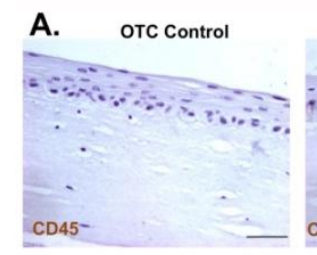

B.

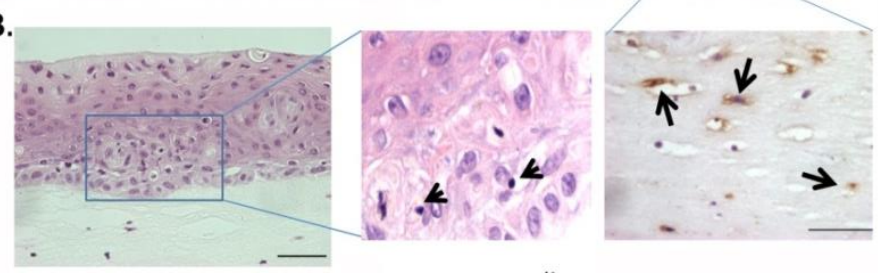

C.

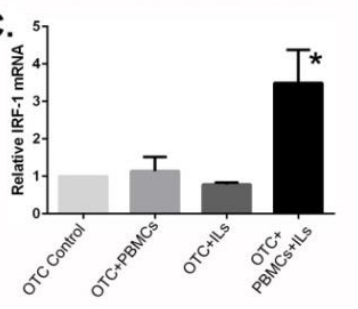

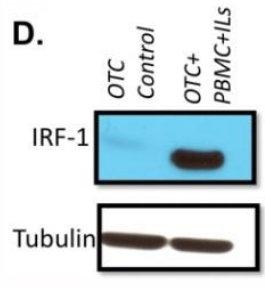

Figure 16. Organotypic culture system allows the proliferation and activation of immune cells. (A) Representative pictures show IHC staining for $\mathrm{CD}_{4} 5^{+}$cells, a marker of leukocytes, in OTC control (left panel), OTC+PBMCs (center panel), and OTC+PBMC+IL (right panel) cultures. Scale bar represent $50 \mu \mathrm{m}$. Inset: Arrow pointing towards positive $\mathrm{CD} 45^{+}$cells in the collagen matrix of the OTC+PBMC+IL culture. (B) Representative $\mathrm{H} \& \mathrm{E}$ staining shows the presence of infiltrating lymphocytes in the OTC+PBMC+IL epithelium (black arrows). Inset: Higher power view of infiltrating lymphocytes. (C) qPCR quantitation of relative mRNA expression of IRF-1 in the epithelium of the OTC cultures. Data are presented as mean \pm SEM. $n=3$ for OTC + PBMC and OTC + IL; $n=7$ for OTC control and OTC+PBMC+IL. * significantly differs from all others by ANOVA and TUKEY Rank Mean testing, $P \leq 0.05$ (D) Representative Western Blot analysis for IRF-1 protein levels in the epithelium from the OTC control and OTC+PBMC+ILs-treated cultures. Blots were stripped and reprobed for the loading control tubulin. 


\subsubsection{Inflammatory OTC environment induces changes in epithelial morphology}

We next sought to identify the effects of activated immune cells on the overlying EECs. To control for the effects of IL-2, IL-7, and IL-15, or the effects of PBMCs alone, OTC cultures with interleukins or immune cells alone were established, in addition to the combined OTC+PBMCs+ILs. These OTC cultures were fixed and embedded and then stained with hematoxylin and eosin to examine for morphologic changes in the epithelium. Cultures with cytokine-cocktail treated PBMCs displayed a significant increase in epithelial thickening, both in the basal and suprabasal compartments (Figure 17A-D). This doubling of epithelial thickness in the OTC cultures was highly significant and confirmed by measurements across multiple cultures (Figure 17E).

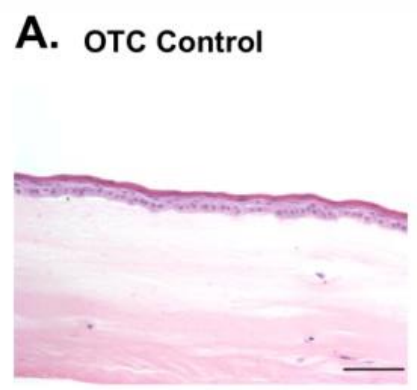

C. OTC+ ILS

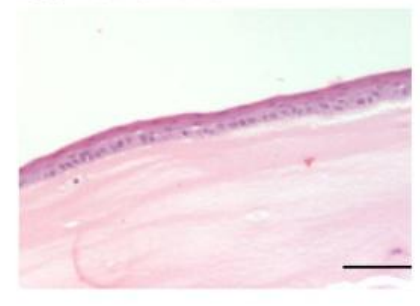

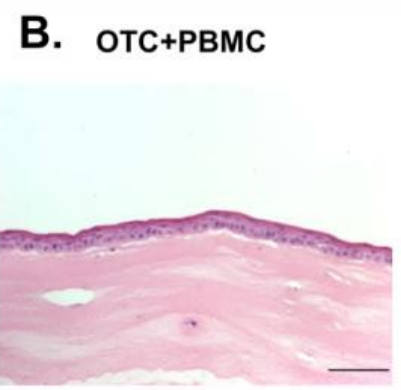

D. OTC+PBMC+ILS

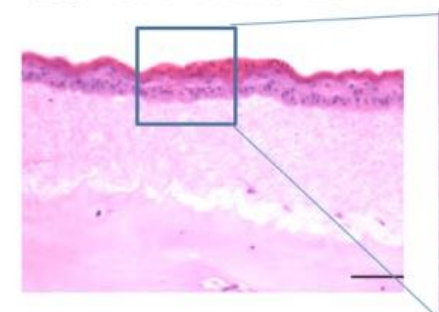

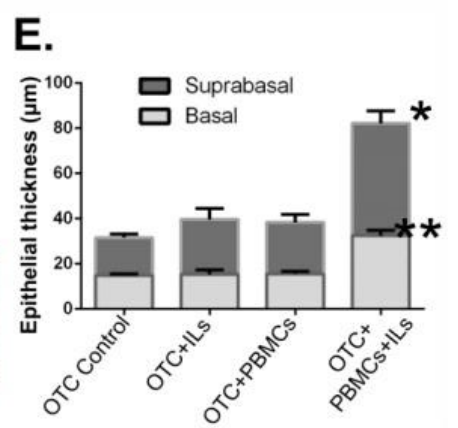

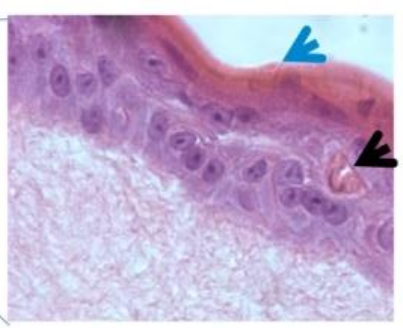

Figure 17. Morphological effects of activated immune cells on esophageal epithelium. Representative pictures of hematoxylin-eosin staining show the morphological differences of OTCs under different culture conditions, including (A) Control OTC, (B) OTC with only PBMCs added (OTC+PBMC), (C) OTC with only IL-2, IL-7, and IL-15 added (OTC+IL), and (D) OTC with both PBMCs and the interleukin cocktail (OTC+PMBC+IL). Inset: significant epithelial thickening was observed together with hyperkeratinization (blue arrow) and regenerative keratin pearls (black arrow) only in the OTC+PBMC+IL culture. These changes were not present in control cultures. Scale bar represent $50 \mu \mathrm{m}$. (E) Quantification of epithelial thickness in microns, measured in 4-5 regions on each section and from three different tissue sections per culture, three separate cultures in total for each treatment. Data are presented as mean \pm SEM. $\mathrm{n}=3$ for all cultures. * and ** significantly differs from all others by ANOVA and TUKEY Rank Mean testing, $P \leq 0.05$ 


\subsubsection{The pro-inflammatory environment modeled with the OTC culture system alters cell proliferation and cell death in the epithelium}

The thickening of the OTC epithelium in the acute inflammatory environment suggested there might be changes in epithelial cell proliferation. We examined for changes in proliferative rates by staining for the proliferation marker Ki-67 in the epithelial cell layer. Basal epithelial cell proliferation in the OTC epithelium was noticeably enhanced in the OTC cultures with PBMCs and the interleukin cocktail when compared to controls (Figure 18A). There was a significant increase in $\mathrm{Ki}-67^{+}$cells, as compared to controls, when quantified across multiple cultures (Figure 18B).
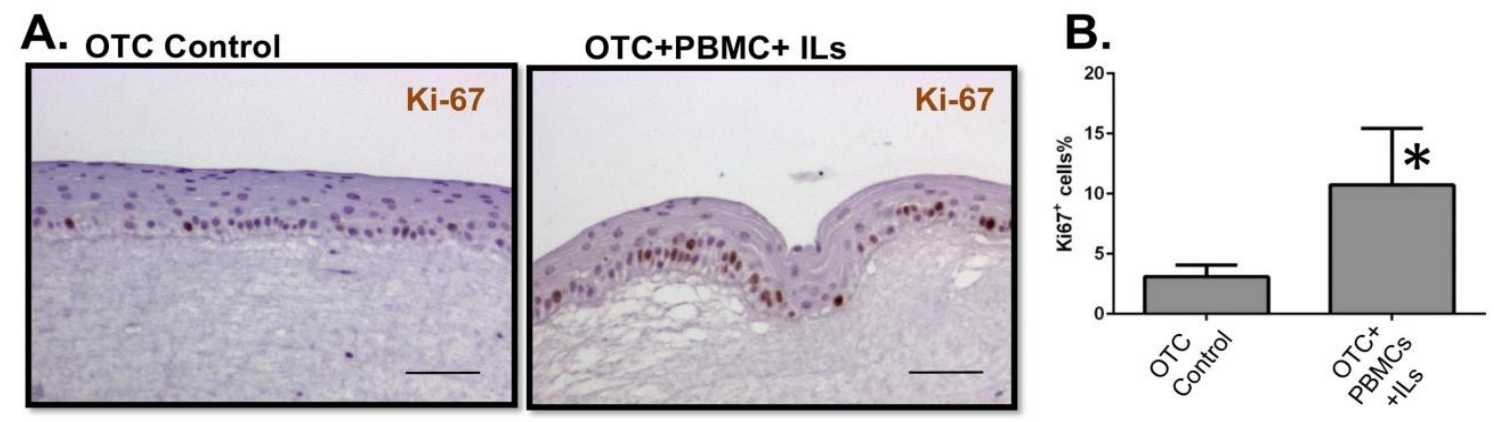

Figure 18. The acute inflammatory environment induces OTC epithelial cell proliferation. (A) Representative Ki-67 immunohistochemical staining in control OTC culture and the OTC culture treated with both PBMCs and the proinflammatory IL-cocktail. Scale bar represents $50 \mu \mathrm{m}$. (B) Quantitation of Ki-67 positive staining. The number of $\mathrm{Ki} 67^{+}$cells was expressed as a percentage of the total number of keratinocytes in a counted field. Data are presented as mean \pm SEM. $\mathrm{n}=3$ cultures per condition, with 500 cells counted per culture. * Significantly differs from OTC control by unpaired Student's T Test, $P \leq 0.0001$.

This elevated proliferative rate was off-set in part by increased epithelial cell apoptosis. This increased level of cell death was confirmed and quantified by TUNEL staining. While there were rare $\mathrm{TUNEL}^{+}$cells in the control OTC cultures (Figure 19B), there was significantly increased numbers of TUNEL ${ }^{+}$epithelial cells in the epithelium of the OTC cultures with the acute-inflammatory environment (Figure 19B). Counts of apoptotic cells over multiple OTC+PBMC+IL cultures revealed a 10 -fold increase in $\mathrm{TUNEL}^{+}$cells as compared to control OTC cultures (Figure 19C). Together these findings support the conclusion that an acute inflammatory environment in the OTC culture system induces epithelial responses including increased epithelial cell apoptosis and proliferation. 
A

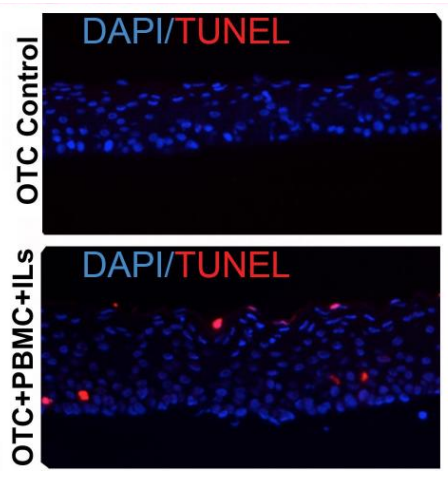

B

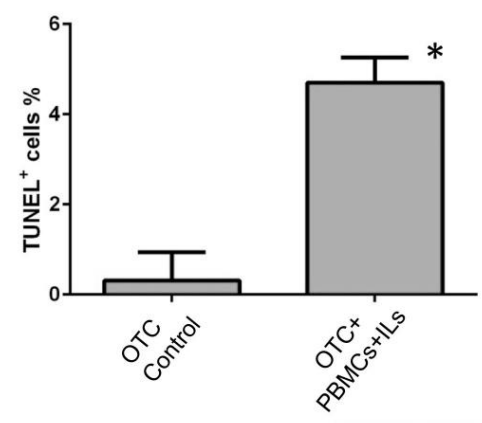

Figure 19. Epithelial cell apoptosis is significantly increased in OTC cultures treated with PBMCs and IL-2, IL-7, and IL-15. (A) Representative epiflourescence images of combined nuclear DAPI (blue) and the apoptosis marker TUNEL (red) staining in OTC control and OTC+PBMC+IL cultures. (B) Quantitative analysis of TUNEL positive cells. TUNEL positive cells were expressed as a percentage of the total number DAPI stained cells in a field. Data are presented as mean \pm SEM. $n=3$ cultures per condition, with 500 cells counted per culture. * Significantly differs from OTC control by unpaired Student's T Test, $\mathrm{p} \leq 0.005$. 


\section{DISCUSSION}

In the first part of this thesis we characterized the main $\mathrm{pH}_{\mathrm{i}}$ regulatory mechanisms of the EECs. The preservation of physiological $\mathrm{pH}_{\mathrm{i}}$ is critical for cell survival and it is mediated through intracellular buffers and ion transporters of the membrane. Ion transporters are part of the esophageal epithelial defense and play crucial role in the protection of gastric and bile acid induced esophageal injury. In contrast to the SE, publications in connection with the ion transport mechanisms of the metaplastic mucosa are lacking, therefore the function and expression of these transporters were investigated on Barrett's derived cells and tissues.

Using functional and molecular biology methods, we determined that Barrett's derived EECs display three main functionally active ion transporters: the NHE, the NBC and the CBE isoform Slc26a6, similarly to other epithelial cells in the gastrointestinal tract. $(75,86,87)$ Using NHE isoform specific inhibitor HOE-642, we determined that NHE-1 and NHE-2 are participating in the restoration of $\mathrm{pH}_{\mathrm{i}}$ which is rather attributable to NHE-1. This finding was in accordance with Goldman et al. who found that $60 \%$ of $\mathrm{pH}_{\mathrm{i}}$ recovery is mediated through NHE-1. (44) Furthermore, we determined that NHE and NBC contribute equally to the alkalization of CP-A and CP-D cells.

To determine the effects of bile acids, we designed a bile acid mixture mimicking the bile acid composition of the refluxate under pathophysiological conditions. Since bile acids are known to induce many intracellular processes like $\mathrm{Ca}^{2+}$ signaling, we investigated the effect of $\mathrm{BAC}$ on $\left[\mathrm{Ca}^{2+}\right]_{\mathrm{i}}$ both under neutral $(\mathrm{pH}=7.5)$ and acidic $(\mathrm{pH}=5.5)$ conditions. We found that administration of bile acids induced dose-dependent $\mathrm{Ca}^{2+}$-elevation in the cells which was more pronounced under acidic condition. Our findings were in agreement with observations of other laboratories that demonstrated that exposure CP-A cells or mouse EECs to DC or acidic media induced intracellular $\mathrm{Ca}^{2+}$ elevation. $(88,89)$ Furthermore, we investigated the potential source of intracellular $\mathrm{Ca}^{2+}$ release. We showed that caffeine, an inhibitor of $\mathrm{IP}_{3}$-mediated $\mathrm{Ca}^{2+}$ responses, completely inhibited the bile acid-induced $\mathrm{Ca}^{2+}$ signaling in the absence of extracellular $\mathrm{Ca}^{2+}$, suggesting the involvement of $\mathrm{IP}_{3}$ receptors in the bile acid-induced $\mathrm{Ca}^{2+}$ release, similarly to colonic crypts, hepatocytes, or pancreatic ducts and acini. $(71,86,90,91) \mathrm{Gd}^{3+}$, a known inhibitor of plasma membrane $\mathrm{Ca}^{2+}$ entry channels, strongly blocked the bile acid-induced $\mathrm{Ca}^{2+}$ signaling indicating that bile acids also promote the influx of extracellular $\mathrm{Ca}^{2+}$. The exact mechanism by which bile acids induce the entry of extracellular $\mathrm{Ca}^{2+}$ is not known. In rat hepatocytes, bile acids directly 
stimulate store-operated $\mathrm{Ca}^{2+}$ channels on the plasma membrane (92); however, further investigations are necessary to identify those $\mathrm{Ca}^{2+}$ channels that contribute to the effect of bile acids on the esophagus.

Since preservation of $\mathrm{pH}_{\mathrm{i}}$ is dependent upon the activity of ion transporters in the next series of experiments we investigated the acute response of the previously characterized ion transporters upon exposure to BAC. Administration of BAC dose dependently decreased the activity of NHEs (both NHE1 and NHE2), whereas stimulated the activities of NBC and Slc26a6 in CP-A cells. Inhibition of NHEs probably contributes to the acidification of the CP-A cells. In contrast, the acidification and the consequent cell damage is prevented by the increased activity of the $\mathrm{HCO}_{3}{ }^{-}$import system through the NBC. In addition, the efflux of $\mathrm{HCO}_{3}{ }^{-}$through the $\mathrm{Cl}^{-} / \mathrm{HCO}_{3}{ }^{-}$exchanger, Slc26a6 also plays an important role in the protection of the cells by the neutralization of the cell environment in the surface mucus layer. We speculate that the increased activities of NBC and Slc26a6 probably compensate the decreased NHE activity and therefore try to maintain the acid/base equilibrium of the cells. Interestingly, administration of BAC stimulated NHE activity in CP-D cells. This difference to CP-A cells can be explained by the advanced stage of CP-D cells. It has been described earlier that dysplastic Barrett's mucosa has more severe and prolonged acidic and biliary reflux exposure. (93) Furthermore, it has also been observed that CPD cells are more resistant to GERD-like stimuli compared with CP-A cells. (94) The mechanism for this alteration and its potential physiological role cannot be explained by the present studies and are areas of focus for future work.

The underlying mechanism by which bile acids exert their stimulatory/inhibitory effects has also been investigated. Previous studies have demonstrated that the effect of bile acids on ion transporters is mediated by transient elevation of $\left[\mathrm{Ca}^{2+}\right]_{i} .(71,86)$ Our results have shown that chelation of $\left[\mathrm{Ca}^{2+}\right]_{i}$ by BAPTA-AM almost completely abolished both the inhibitory and stimulatory effect of BAC on ion transporters. Although we have not studied the mechanism by which $\mathrm{Ca}^{2+}$ mediate the effect of bile acids on CP-A cells, we propose that the activation of Slc26a6 is connected to the activation of $\mathrm{Ca}^{2+}$-activated ion channels, such as $\mathrm{Ca}^{2+}$-activated $\mathrm{Cl}^{-}$channels or $\mathrm{K}^{+}$channels, as demonstrated in other epithelia. (95-97) In contrast to Slc26a6, high levels of $\left[\mathrm{Ca}^{2+}\right]_{\mathrm{i}}$ strongly inhibited NHE activity. Previous studies on rabbit ileal brush-border membrane and renal NHE containing proteoliposomes have demonstrated that the phosphorylation of specific proteins by the $\mathrm{Ca}^{2+} /$ calmodulin cascade results in a robust blockade of NHE. $(98,99)$ Taken 
together these data indicate that the increased levels of $\mathrm{Ca}^{2+}$ probably do not directly modulate the activity of ion transporters; however, further investigations are needed to identify those intracellular signaling pathways or molecules that are involved in this process.

In the next step, in order to mimic chronic bile acid challenge, we performed a 7-day treatment with BAC under neutral and acidic conditions to investigate the role of ion transporters in cellular adaptation. Following treatment the mRNA expression of all of the investigated transporters in CP-A cells and the mRNA expression of NHE1 and NBC in CP-D cells were increased under neutral $\mathrm{pH}$. In contrast, the expression of the transporters did not change significantly under acidic conditions in CP-A cells; moreover, the cell number dramatically decreased. In contrast, the expression of NHE1 significantly increased in CP-D cells at pH 5.5. We could also confirm the increased expression of NHE1 at protein level. To further extend these studies we investigated the expression profile of these transporters in human derived biopsy samples from the normal squamous and metaplastic mucosa of BE patients. In Europe, BE is characterized by the presence of macroscopically visible metaplastic columnar epithelium. (100) In contrast, in the United States only the intestinal type of metaplasia is considered to be BE. (13) Thus we divided our samples into intestinal and non-intestinal groups and analyzed them separately. NHEs, NBC, and Slc26a6 displayed higher mRNA levels in both intestinal and nonintestinal metaplasia compared with normal tissue. Increased protein expression of NHE1 and NHE2 was also confirmed in BE. These results are consistent with the report by Goldman et al. (44) that demonstrated upregulation of NHE-1 in BE compared with normal epithelium both at mRNA and protein levels in biopsy samples and cell lines. Moreover, we observed strong apical staining for NHE-2 in BE biopsy samples, similarly to findings of other laboratories in various tissues. (101-103) These findings support our hypothesis that the overexpression of ion transporters is probably a defensive or adaptive mechanism by which the cells try to compensate the toxic effects of bile acids.

In the second part of the thesis we investigated the potential contribution of autophagy in the pathogenesis of BE. Autophagy is a highly conserved cellular mechanism which degrades the unnecessary cellular components by lysosome dependent fashion. Pro-survival function of autophagy has an adaptive role and activated upon cellular stress like starvation or oxidative stress in normal, healthy tissue. $(48,50,51)$ However, in tumor tissue autophagy can contribute to increased cell survival: tumor cells located within a hypoxic and nutritionally starved centers 
typically utilize autophagy to enhance tumor cell survival. (48) This feature has an important therapeutic implication as well: pharmacological autophagy inhibitors including CQ and its derivatives have been effective in enhancing the cytotoxic effects of radiation or chemotherapy and improving survival in several trials. $(104,105)$ However, the role of autophagy in premalignant diseases like BE is less characterized. Several previous observations have demonstrated that elevated level of ROS in response to GERD is a key step driving BE onset and progression to EAC. $(27,55-57)$ Given this well-established relationship between elevated ROS and an increase in autophagy steady- state levels, suprisingly this pathway has not yet been extensively studied in GERD and BE. To date, there is a single published paper on this subject, and the focus of this work is on Beclin-1 and how its loss correlates with progression to EAC. (58) In present study we aimed to determine the functional role of autophagy in various esophageal cell lines. We found that acid injury alone, in the absence of bile acids, was sufficient to induce autophagic response in all tested cell lines. Furthermore, we determined that autophagy inhibition with CQ further increased intracellular ROS level after acid pulse treatment in non-transformed cell lines (STR and CP-A). This significant increase is consistent with autophagy acting to reduce intracellular ROS stress after an injury. (106) However, this significant increase was not observed in dysplastic cells (CP$\mathrm{D}$ and OE-19), suggesting that these cells do not utilize autophagy to manage oxidative stress induced by an acidic environment. Most significantly, we observed that the inhibition of autophagy after an acidic insult leads to significantly greater cell death at $24 \mathrm{~h}$ in all cell lines tested. This suggests two important role for autophagy in esophageal cells in response to an acid insult: the modulation of the oxidative stress and enhancing cell survival. One unexpected finding from our study is that in dysplastic CP-D and OE19 cells, Cyto-ID, and LC3-GFP appear to mark different vesicle subsets. This is the only explanation available to explain the discordance between these two well-established approaches to quantifying autophagy vesicle content of cells. We tend to favor the LC3-GFP results as being more representative of the autophagy response, given that control OE19 cells by observed by transmission electron microscopy had vesicles but these were not double-walled and did not contain cellular debris (data not shown). Thus the Cyto-ID dye identifies these vesicles based on a shared biochemistry with autophagosomes. However, quite unexpectedly only in OE19 cells, the Cyto-ID signal was lost after acid treatment. Together these findings do suggest autophagosome biochemistry may be different in the dysplastic cell line. The 
mechanism for this alteration, and the physiologic role it may play, cannot be determined by the present studies and needs to be further explored.

Research into GERD has previously been limited by the availabilty of suitable laboratory approaches to model this conditions. Much of the past work has relied upon the availability of human patient biopsies (107), which are a precious commodity and largely suitable for descriptive studies only. Commercially available immortalized cell lines, including representing normal squamous, Barrett's, and EAC, are maintained under 2D culture conditions and are the most convenient and widely used in vitro tools. (60-62) However, 2D cultured immortalized cell lines can not reflect appropriately the complex interactions between epithelial cells and their microenvironment. (108) Animal models are another important tools of biomedical research. An ideal animal model should represent the human etiology, pathogenesis and molecular features of the disease and these models leave significant amounts of unmet needs. Surgical models such as esophagojejunostomy, esophagoduodenal anastomosis, and esophagogastroduodenal anastomosis in rats (109-114) and less frequently in mice (115) have been the primary methods used to mimic reflux induced mucosal injury. However, the use of rats has been limited due to the paucity of genetically modified rat transgenic lines which precludes the conduction of mechanistic genetic studies. In contrast, while there are an abundance of suitable transgenic mouse lines for mechanistic studies $(13,116-118)$ the surgical procedure in mice is technically much more challanging, limiting its broader application. A transgenic mouse model for esophagitis that progresses to BE and EAC has been described. (13) It utilizes an Epstein-Barr virus L2 promoter to over-express human IL-1 $\beta$ in the oral cavity, esophagus, and squamous forestomach of mice. These L2-IL-1 $\beta$ mice develop a chronic (119) inflammatory esophagitis by 3 months that is followed subsequently by the development of a columnar metaplasia with intestinal features and later dysplasia and cancer. However, in this transgenic line the IL-1 $\beta$ is constitutively expressed. This is therefore a model of chronic inflammation rather than suitable for studies of the effects of an acute inflammatory environment on epithelial cell responses. Thus, the limitations of the aforementioned in vitro and in vivo approaches pose a significant constraint to the field. Disease models for GERD and esophagitis based on 3D human cell and tissue culture systems that recapitulate in vivo growth and differentiation in inflammatory-associated environment would enhance our understanding of disease progression and improve our ability to test for disease prevention strategies. 
Therefore, in the third part of the thesis we further expanded the original protocol of OTC in order to model esophageal inflammation and get a better insight into the interactions between the esophageal epithelium and the acute inflammatory environment. We found that OTC is an appropriate culture system to maintain immune cell viability and cytokine responsiveness, and we demonstrated that human PBMCs incorporated into the OTC culture respond approapriately to pro-inflammatory cytokines. Moreover, the epithelial responses to our inflammatory environment are in accordance with previous descriptions of in vivo responses to reflux esophagitis. (120) We observed changes in epithelial morphology in our OTC cultures, including increased epithelial thickening, enhanced basal cell proliferation, elevated levels of epithelial cell apoptosis, and hyperkeratinization. Biopsy samples from reflux esophagitis patients have similarly displayed basal cell hyperplasia, and increased epithelial cell apoptosis in the setting of an immune cell infiltration. (120) Similar findings has been described in rat reflux models as well. (121) Our observations here imply that a significant portion of these epithelial responses in GERD esophagitis are immune cell mediated, rather than directly caused by the actions of the gastric relfuxate, and therefore support this recently proposed alternative mechanism for the tissue injury. 


\section{CONCLUSIONS AND NEW RESULTS}

- In the first part of the thesis we characterized the role of ion transport mechanisms in metaplastic EECs. Our findings further confirm the notion that metaplastic change of the normal $\mathrm{SE}$ to $\mathrm{BE}$ may be an adaptive process to regulate $\mathrm{pH}_{\mathrm{i}}$ after exposure to gastric and bile acid. Our study may help to better understand the metaplastic esophageal response to injury and the role of ion transporters in this process. We believe that pharmacological activation of ion transporters increases epithelial resistance in an acidic environment and therefore may protect the esophageal mucosa against the injurious bile acids.

- In the second part of the thesis we demonstrated that autophagy is activated in response to GERD-like acidic stress where it functions to reduce intracellular oxidative stress and improve cell survival. We hypothesize that autophagy may be a novel therapeutic target in $\mathrm{BE}$ that deserves to be explored. Our work exploring the activity of autophagy in BE and EAC is thus important both for mechanistic insights as well as the potential application of novel therapeutic agents to intervene in BE and EAC onset and progression.

- In the final part of the thesis we demonstrated that OTC is a useful tool to model esophageal inflammation since it can reproduce the characteristics of esophagitis in a well-controlled in vitro setting. In conclusion, our results further highlight the importance of immune-cell mediated esophageal injury and supports the further use of this new platform to charachterize the underlying molecular events in inflammation-induced esophagitis, BE, and carcinogenesis .

In summary, our studies provided important data on the pathogensis of GERD and its complications, which may both enhance our understanding of these conditions and open new perspectives for further research. 


\section{ACKNOWLEDGEMENTS}

I would like to thank all of the people who have helped and inspired me during my work.

I am grateful to Prof. Dr. András Varró, the head of Department of Pharmacology and Pharmacotherapy and to Prof. Dr. György Ábrahám and Prof. Dr. Tibor Wittmann, the current and former head of the First Department of Medicine, who gave me the opportunity to work at their Departments.

I would like to say thank you to my supervisors, Dr. Viktória Venglovecz and Dr. András Rosztóczy for their help during my Ph.D. studies.

I also would like to say thank you to Prof. Dr. Péter Hegyi and Prof. Dr. Zoltán Rakonczay Jr. besides the opportunity to do my research in their laboratory, for their trust, help, support and constructive advices. In addition, I would like to thank my colleagues: Dr. Máté Katona, Dr. Krisztina Tóth, Dr. Anita Balázs, Zsolt Balla, Dr. Balázs Kui, Dr. Eszter Kormányos, Tamara Madácsy, Dr. József Maléth, Dr. Petra Pallagi, Dr. Eszter Végh, for all the help and entertainment they provided. This work would not have been possible to accomplish without the assistance and work of Tünde Pritz, Miklósné Árva, Rea Fritz, Edit Magyarné Pálfi and the assistans of the Endoscopy laboratory. My special thanks goes to Zoltánné Fuksz whose continuous attention and care established the proper conditions of our tissue culture laboratory.

I would like to express my gratitude to Dr. John P. Lynch from the University of Pennsylvania, Perelman School of Medicine, who was a great mentor of me during my staying in his lab.

Last but not least, my deepest gratitude goes to my parents and Norbert Pardi for their love, support and encouragement; this dissertation would have been impossible to accomplish without their help. I would like to dedicate this thesis to them.

This work was supported by the National Development Agency grants (TÁMOP-4.2.2.A11/1/KONV-2012-0035, TÁMOP-4.2.2.A-11/1/KONV-2012-0073, TÁMOP-4.2.2- 11/1/KONV2012-0052), and as part of the NCI BETRNet program (CA163004-AR, GG, GF, and JL), and a NIH career development award to JPL (OD 012097). This work was also supported by core facilities (Molecular Pathology and Imaging, Cell Culture, and Molecular Biology Cores) of the Center for Molecular Studies in Digestive and Liver Disease at the University of Pennsylvania (P30-DK050306 and PO1 CA098101) and a scholarship from the Rosztóczy Foundation. 


\section{REFERENCES}

1. Jones R, Galmiche JP. Review: what do we mean by GERD?--definition and diagnosis. Aliment Pharmacol Ther. 2005;22 Suppl 1:2-10.

2. Pace F, Bianchi Porro G. Gastroesophageal reflux disease: a typical spectrum disease (a new conceptual framework is not needed). Am J Gastroenterol. 2004;99(5):946-9.

3. Kulig M, Leodolter A, Vieth M, Schulte E, Jaspersen D, Labenz J, et al. Quality of life in relation to symptoms in patients with gastro-oesophageal reflux disease-- an analysis based on the ProGERD initiative. Aliment Pharmacol Ther. 2003;18(8):767-76.

4. Dent J, El-Serag HB, Wallander MA, Johansson S. Epidemiology of gastro-oesophageal reflux disease: a systematic review. Gut. 2005;54(5):710-7.

5. Yeh C, Hsu CT, Ho AS, Sampliner RE, Fass R. Erosive esophagitis and Barrett's esophagus in Taiwan: a higher frequency than expected. Digestive diseases and sciences. 1997;42(4):702-6. 6. Mizushima N. Methods for monitoring autophagy using GFP-LC3 transgenic mice. Methods Enzymol. 2009;452:13-23.

7. Vakil N, van Zanten SV, Kahrilas P, Dent J, Jones R. The Montreal definition and classification of gastroesophageal reflux disease: a global evidence-based consensus. The American journal of gastroenterology. 2006;101(8):1900-20; quiz 43.

8. Rubenstein JH, Morgenstern H, Appelman H, Scheiman J, Schoenfeld P, McMahon LF, Jr., et al. Prediction of Barrett's esophagus among men. The American journal of gastroenterology. 2013;108(3):353-62.

9. Martinez SD, Malagon IB, Garewal HS, Cui H, Fass R. Non-erosive reflux disease (NERD)--acid reflux and symptom patterns. Aliment Pharmacol Ther. 2003;17(4):537-45.

10. Hershcovici T, Fass R. Nonerosive Reflux Disease (NERD) - An Update. Journal of neurogastroenterology and motility. 2010;16(1):8-21.

11. Tobey NA, Carson JL, Alkiek RA, Orlando RC. Dilated intercellular spaces: a morphological feature of acid reflux--damaged human esophageal epithelium. Gastroenterology. 1996;111(5):1200-5. 
12. Ronkainen J, Talley NJ, Storskrubb T, Johansson SE, Lind T, Vieth M, et al. Erosive esophagitis is a risk factor for Barrett's esophagus: a community-based endoscopic follow-up study. Am J Gastroenterol. 2011;106(11):1946-52.

13. Quante M, Bhagat G, Abrams JA, Marache F, Good P, Lee MD, et al. Bile acid and inflammation activate gastric cardia stem cells in a mouse model of Barrett-like metaplasia. Cancer cell. 2012;21(1):36-51.

14. Hartman KG, Bortner JD, Jr., Falk GW, Ginsberg GG, Jhala N, Yu J, et al. Modeling human gastrointestinal inflammatory diseases using microphysiological culture systems. Experimental biology and medicine (Maywood, NJ). 2014;239(9):1108-23.

15. Ostrowski J, Mikula M, Karczmarski J, Rubel T, Wyrwicz LS, Bragoszewski P, et al. Molecular defense mechanisms of Barrett's metaplasia estimated by an integrative genomics. Journal of molecular medicine (Berlin, Germany). 2007;85(7):733-43.

16. Shaheen NJ. What is behind the remarkable increase in esophageal adenocarcinoma? Am J Gastroenterol. 2014;109(3):345-7.

17. Hur C, Miller M, Kong CY, Dowling EC, Nattinger KJ, Dunn M, et al. Trends in esophageal adenocarcinoma incidence and mortality. Cancer. 2013;119(6):1149-58.

18. DeMeester SR, DeMeester TR. Columnar mucosa and intestinal metaplasia of the esophagus: fifty years of controversy. Annals of surgery. 2000;231(3):303-21.

19. Hirota WK, Loughney TM, Lazas DJ, Maydonovitch CL, Rholl V, Wong RK. Specialized intestinal metaplasia, dysplasia, and cancer of the esophagus and esophagogastric junction: prevalence and clinical data. Gastroenterology. 1999;116(2):277-85.

20. Herbella FA, Patti MG. Gastroesophageal reflux disease: From pathophysiology to treatment. World journal of gastroenterology. 2010;16(30):3745-9.

21. Rosztoczy A, Izbeki F, Roka R, Nemeth I, Gecse K, Vadaszi K, et al. The evaluation of oesophageal function in patients with different types of oesophageal metaplasia. Digestion. 2011;84(4):273-80.

22. Marshall RE, Anggiansah A, Owen WJ. Bile in the oesophagus: clinical relevance and ambulatory detection. The British journal of surgery. 1997;84(1):21-8.

23. Jaiswal K, Lopez-Guzman C, Souza RF, Spechler SJ, Sarosi GA, Jr. Bile salt exposure increases proliferation through p38 and ERK MAPK pathways in a non-neoplastic Barrett's cell line. American journal of physiology Gastrointestinal and liver physiology. 2006;290(2):G335-42. 
24. Burnat G, Rau T, Elshimi E, Hahn EG, Konturek PC. Bile acids induce overexpression of homeobox gene CDX-2 and vascular endothelial growth factor (VEGF) in human Barrett's esophageal mucosa and adenocarcinoma cell line. Scandinavian journal of gastroenterology. 2007;42(12):1460-5.

25. Kazumori H, Ishihara S, Rumi MA, Kadowaki Y, Kinoshita Y. Bile acids directly augment caudal related homeobox gene $\mathrm{Cdx} 2$ expression in oesophageal keratinocytes in Barrett's epithelium. Gut. 2006;55(1):16-25.

26. Clemons NJ, McColl KE, Fitzgerald RC. Nitric oxide and acid induce double-strand DNA breaks in Barrett's esophagus carcinogenesis via distinct mechanisms. Gastroenterology. 2007;133(4):1198-209.

27. Dvorak K, Payne CM, Chavarria M, Ramsey L, Dvorakova B, Bernstein H, et al. Bile acids in combination with low $\mathrm{pH}$ induce oxidative stress and oxidative DNA damage: relevance to the pathogenesis of Barrett's oesophagus. Gut. 2007;56(6):763-71.

28. Schweitzer EJ, Harmon JW, Bass BL, Batzri S. Bile acid efflux precedes mucosal barrier disruption in the rabbit esophagus. American Journal of Physiology-Gastrointestinal and Liver Physiology. 1984;247(5):G480-G5.

29. Tobey NA, Hosseini SS, Caymaz-Bor C, Wyatt HR, Orlando GS, Orlando RC. The role of pepsin in acid injury to esophageal epithelium. Am J Gastroenterol. 2001;96(11):3062-70.

30. Vaezi MF, Richter JE. Role of acid and duodenogastroesophageal reflux in gastroesophageal reflux disease. Gastroenterology. 1996;111(5):1192-9.

31. Souza RF, Huo X, Mittal V, Schuler CM, Carmack SW, Zhang HY, et al. Gastroesophageal reflux might cause esophagitis through a cytokine-mediated mechanism rather than caustic acid injury. Gastroenterology. 2009;137(5):1776-84.

32. Dunbar KB, Agoston AT, Odze RD, Huo X, Pham TH, Cipher DJ, et al. Association of Acute Gastroesophageal Reflux Disease With Esophageal Histologic Changes. Jama. 2016;315(19):2104-12.

33. Orlando RC. Review article: oesophageal mucosal resistance. Aliment Pharmacol Ther. 1998;12(3):191-7.

34. Orlando RC. Esophageal epithelial defense against acid injury. Journal of clinical gastroenterology. 1991;13:S6. 
35. Awayda MS, Bengrine A, Tobey NA, Stockand JD, Orlando RC. Nonselective cation transport in native esophageal epithelia. American journal of physiology Cell physiology. 2004;287(2):C395-402.

36. Tobey NA, Argote CM, Awayda MS, Vanegas XC, Orlando RC. Effect of luminal acidity on the apical cation channel in rabbit esophageal epithelium. American Journal of PhysiologyGastrointestinal and Liver Physiology. 2007;292(3):G796-G805.

37. Tobey NA, Reddy SP, Keku TO, Cragoe EJ, Jr., Orlando RC. Mechanisms of HCl-induced lowering of intracellular $\mathrm{pH}$ in rabbit esophageal epithelial cells. Gastroenterology. 1993;105(4):1035-44.

38. Tobey NA, Reddy SP, Khalbuss WE, Silvers SM, Cragoe EJ, Jr., Orlando RC. Na(+)dependent and -independent $\mathrm{Cl}-/ \mathrm{HCO} 3$ - exchangers in cultured rabbit esophageal epithelial cells. Gastroenterology. 1993;104(1):185-95.

39. Layden TJ, Schmidt L, Agnone L, Lisitza P, Brewer J, Goldstein JL. Rabbit esophageal cell cytoplasmic $\mathrm{pH}$ regulation: role of $\mathrm{Na}(+)-\mathrm{H}+$ antiport and $\mathrm{Na}(+)$-dependent $\mathrm{HCO} 3$ - transport systems. The American journal of physiology. 1992;263(3 Pt 1):G407-13.

40. Shallat S, Schmidt L, Reaka A, Rao D, Chang EB, Rao MC, et al. NHE-1 isoform of the $\mathrm{Na}+\mathrm{H}+$ antiport is expressed in the rat and rabbit esophagus. Gastroenterology. 1995;109(5):1421-8.

41. Demaurex N, Grinstein S. Na+/H+ antiport: modulation by ATP and role in cell volume regulation. The Journal of experimental biology. 1994;196:389-404.

42. Fitzgerald RC, Omary MB, Triadafilopoulos G. Altered sodium-hydrogen exchange activity is a mechanism for acid-induced hyperproliferation in Barrett's esophagus. The American journal of physiology. 1998;275(1 Pt 1):G47-55.

43. Wu KL, Khan S, Lakhe-Reddy S, Jarad G, Mukherjee A, Obejero-Paz CA, et al. The NHE1 $\mathrm{Na}+\mathrm{H}+$ exchanger recruits ezrin/radixin/moesin proteins to regulate Akt-dependent cell survival. Journal of Biological Chemistry. 2004;279(25):26280-6.

44. Goldman A, Shahidullah M, Goldman D, Khailova L, Watts G, Delamere N, et al. A novel mechanism of acid and bile acid-induced DNA damage involving $\mathrm{Na}+\mathrm{H}+$ exchanger: implication for Barrett's oesophagus. Gut. 2010;59(12):1606-16.

45. Xie Z, Klionsky DJ. Autophagosome formation: core machinery and adaptations. Nature cell biology. 2007;9(10):1102-9. 
46. Amaravadi RK, Thompson CB. The roles of therapy-induced autophagy and necrosis in cancer treatment. Clinical cancer research : an official journal of the American Association for Cancer Research. 2007;13(24):7271-9.

47. He C, Klionsky DJ. Regulation mechanisms and signaling pathways of autophagy. Annual review of genetics. 2009;43:67-93.

48. Mathew R, White E. Autophagy in tumorigenesis and energy metabolism: friend by day, foe by night. Current opinion in genetics \& development. 2011;21(1):113-9.

49. Yang ZJ, Chee CE, Huang S, Sinicrope FA. The role of autophagy in cancer: therapeutic implications. Molecular cancer therapeutics. 2011;10(9):1533-41.

50. Dikic I, Johansen T, Kirkin V. Selective autophagy in cancer development and therapy. Cancer research. 2010;70(9):3431-4.

51. Galluzzi L, Morselli E, Vicencio JM, Kepp O, Joza N, Tajeddine N, et al. Life, death and burial: multifaceted impact of autophagy. Biochemical Society transactions. 2008;36(Pt 5):78690.

52. Whelan KA, Merves JF, Giroux V, Tanaka K, Guo A, Chandramouleeswaran PM, et al. Autophagy mediates epithelial cytoprotection in eosinophilic oesophagitis. Gut. 2016.

53. Fritz T, Niederreiter L, Adolph T, Blumberg RS, Kaser A. Crohn's disease: NOD2, autophagy and ER stress converge. Gut. 2011;60(11):1580-8.

54. Lynch-Day MA, Mao K, Wang K, Zhao M, Klionsky DJ. The role of autophagy in Parkinson's disease. Cold Spring Harbor perspectives in medicine. 2012;2(4):a009357.

55. Inayama M, Hashimoto N, Tokoro $\mathrm{T}$, Shiozaki H. Involvement of oxidative stress in experimentally induced reflux esophagitis and esophageal cancer. Hepatogastroenterology. 2007;54(75):761-5.

56. Lee JS, Oh TY, Ahn BO, Cho H, Kim WB, Kim YB, et al. Involvement of oxidative stress in experimentally induced reflux esophagitis and Barrett's esophagus: clue for the chemoprevention of esophageal carcinoma by antioxidants. Mutation research. 2001;480-481:189200.

57. Sihvo EI, Salminen JT, Rantanen TK, Ramo OJ, Ahotupa M, Farkkila M, et al. Oxidative stress has a role in malignant transformation in Barrett's oesophagus. International journal of cancer. 2002;102(6):551-5. 
58. Roesly HB, Khan MR, Chen HD, Hill KA, Narendran N, Watts GS, et al. The decreased expression of Beclin-1 correlates with progression to esophageal adenocarcinoma: the role of deoxycholic acid. American journal of physiology Gastrointestinal and liver physiology. 2012;302(8):G864-72.

59. Jaiswal KR, Morales CP, Feagins LA, Gandia KG, Zhang X, Zhang HY, et al. Characterization of telomerase-immortalized, non-neoplastic, human Barrett's cell line (BAR-T). Diseases of the esophagus : official journal of the International Society for Diseases of the Esophagus / ISDE. 2007;20(3):256-64.

60. Marchetti M, Caliot E, Pringault E. Chronic acid exposure leads to activation of the cdx2 intestinal homeobox gene in a long-term culture of mouse esophageal keratinocytes. Journal of cell science. 2003;116(Pt 8):1429-36.

61. Ouatu-Lascar R, Fitzgerald RC, Triadafilopoulos G. Differentiation and proliferation in Barrett's esophagus and the effects of acid suppression. Gastroenterology. 1999;117(2):327-35.

62. Souza RF, Shewmake K, Terada LS, Spechler SJ. Acid exposure activates the mitogenactivated protein kinase pathways in Barrett's esophagus. Gastroenterology. 2002;122(2):299-307. 63. Nicholson AM, Graham TA, Simpson A, Humphries A, Burch N, Rodriguez-Justo M, et al. Barrett's metaplasia glands are clonal, contain multiple stem cells and share a common squamous progenitor. Gut. 2012;61(10):1380-9.

64. Kalabis J, Wong GS, Vega ME, Natsuizaka M, Robertson ES, Herlyn M, et al. Isolation and characterization of mouse and human esophageal epithelial cells in 3D organotypic culture. Nature protocols. 2012;7(2):235-46.

65. Harada H, Nakagawa H, Oyama K, Takaoka M, Andl CD, Jacobmeier B, et al. Telomerase induces immortalization of human esophageal keratinocytes without p16INK4a inactivation. Molecular cancer research : MCR. 2003;1(10):729-38.

66. Sharma P, Dent J, Armstrong D, Bergman JJ, Gossner L, Hoshihara Y, et al. The development and validation of an endoscopic grading system for Barrett's esophagus: the Prague C \& M criteria. Gastroenterology. 2006;131(5):1392-9.

67. Hegyi P, Rakonczay Z, Jr., Gray MA, Argent BE. Measurement of intracellular pH in pancreatic duct cells: a new method for calibrating the fluorescence data. Pancreas. 2004;28(4):427-34. 
68. Thomas JA, Buchsbaum RN, Zimniak A, Racker E. Intracellular pH measurements in Ehrlich ascites tumor cells utilizing spectroscopic probes generated in situ. Biochemistry. 1979;18(11):2210-8.

69. Hegyi P, Gray MA, Argent BE. Substance P inhibits bicarbonate secretion from guinea pig pancreatic ducts by modulating an anion exchanger. American journal of physiology Cell physiology. 2003;285(2):C268-76.

70. Weintraub WH, Machen TE. pH regulation in hepatoma cells: roles for $\mathrm{Na}-\mathrm{H}$ exchange, $\mathrm{Cl}-\mathrm{HCO} 3$ exchange, and Na-HCO3 cotransport. American Journal of Physiology-Gastrointestinal and Liver Physiology. 1989;257(3):G317-G27.

71. Venglovecz V, Rakonczay Z, Ozsvari B, Takacs T, Lonovics J, Varro A, et al. Effects of bile acids on pancreatic ductal bicarbonate secretion in guinea pig. Gut. 2008;57(8):1102-12.

72. Ghatak S, Reveiller M, Toia L, Ivanov A, Godfrey TE, Peters JH. Bile acid at low pH reduces squamous differentiation and activates EGFR signaling in esophageal squamous cells in 3-D culture. Journal of gastrointestinal surgery : official journal of the Society for Surgery of the Alimentary Tract. 2013;17(10):1723-31.

73. Kauer WK, Peters JH, DeMeester TR, Feussner H, Ireland AP, Stein HJ, et al. Composition and concentration of bile acid reflux into the esophagus of patients with gastroesophageal reflux disease. Surgery. 1997;122(5):874-81.

74. Liu T, Zhang X, So CK, Wang S, Wang P, Yan L, et al. Regulation of Cdx2 expression by promoter methylation, and effects of $\mathrm{Cdx} 2$ transfection on morphology and gene expression of human esophageal epithelial cells. Carcinogenesis. 2007;28(2):488-96.

75. Czepan M, Rakonczay Z, Jr., Varro A, Steele I, Dimaline R, Lertkowit N, et al. NHE1 activity contributes to migration and is necessary for proliferation of human gastric myofibroblasts. Pflugers Archiv : European journal of physiology. 2012;463(3):459-75.

76. Steward MC, Ishiguro H, Case RM. Mechanisms of bicarbonate secretion in the pancreatic duct. Annual review of physiology. 2005;67:377-409.

77. Toth-Molnar E, Venglovecz V, Ozsvari B, Rakonczay Z, Jr., Varro A, Papp JG, et al. New experimental method to study acid/base transporters and their regulation in lacrimal gland ductal epithelia. Investigative ophthalmology \& visual science. 2007;48(8):3746-55. 
78. Maenz DD, Forsyth GW. Calcium ionophore activity of intestinal secretory compounds. An in vitro porcine model for the effects of bile acids, hydroxy-fatty acids and dioctyl sulfosuccinate. Digestion. 1984;30(3):138-50.

79. Oelberg DG, Wang LB, Sackman JW, Adcock EW, Lester R, Dubinsky WP. Bile saltinduced calcium fluxes in artificial phospholipid vesicles. Biochimica et biophysica acta. 1988;937(2):289-99.

80. Heufler C, Topar G, Grasseger A, Stanzl U, Koch F, Romani N, et al. Interleukin 7 is produced by murine and human keratinocytes. J Exp Med. 1993;178(3):1109-14.

81. Fry TJ, Mackall CL. Interleukin-7: from bench to clinic. Blood. 2002;99(11):3892-904.

82. Anderson DM, Kumaki S, Ahdieh M, Bertles J, Tometsko M, Loomis A, et al. Functional characterization of the human interleukin-15 receptor alpha chain and close linkage of IL15RA and IL2RA genes. J Biol Chem. 1995;270(50):29862-9.

83. Steel JC, Waldmann TA, Morris JC. Interleukin-15 biology and its therapeutic implications in cancer. Trends Pharmacol Sci. 2012;33(1):35-41.

84. Dooms H. Interleukin-7: Fuel for the autoimmune attack. J Autoimmun. 2013;45:40-8.

85. Boehm U, Klamp T, Groot M, Howard JC. Cellular responses to interferon-gamma. Annu Rev Immunol. 1997;15:749-95.

86. Pallagi-Kunstár É, Farkas K, Maleth J, Rakonczay Jr Z, Nagy F, Molnar T, et al. Bile acids inhibit $\mathrm{Na}+\mathrm{H}+$ exchanger and $\mathrm{Cl}-/ \mathrm{HCO} 3-$ exchanger activities via cellular energy breakdown and $\mathrm{Ca} 2+$ overload in human colonic crypts. Pflügers Archiv-European Journal of Physiology. 2015;467(6):1277-90.

87. Tóth-Molnár E, Venglovecz V, Ozsvári B, Rakonczay Zn, Varró A, Papp JG, et al. New experimental method to study acid/base transporters and their regulation in lacrimal gland ductal epithelia. Investigative ophthalmology \& visual science. 2007;48(8):3746-55.

88. Goldman A, Chen H, Khan MR, Roesly H, Hill KA, Shahidullah M, et al. The Na+/H+ exchanger controls deoxycholic acid-induced apoptosis by a H+-activated, Na+-dependent ionic shift in esophageal cells. PloS one. 2011;6(8):e23835.

89. Li D, Cao W. Role of intracellular calcium and NADPH oxidase NOX5-S in acid-induced DNA damage in Barrett's cells and Barrett's esophageal adenocarcinoma cells. American journal of physiology Gastrointestinal and liver physiology. 2014;306(10):G863-72. 
90. Devor DC, Sekar MC, Frizzell RA, Duffey ME. Taurodeoxycholate activates potassium and chloride conductances via an IP3-mediated release of calcium from intracellular stores in a colonic cell line (T84). The Journal of clinical investigation. 1993;92(5):2173-81.

91. Gerasimenko JV, Flowerdew SE, Voronina SG, Sukhomlin TK, Tepikin AV, Petersen OH, et al. Bile acids induce $\mathrm{Ca} 2+$ release from both the endoplasmic reticulum and acidic intracellular calcium stores through activation of inositol trisphosphate receptors and ryanodine receptors. The Journal of biological chemistry. 2006;281(52):40154-63.

92. Aromataris EC, Castro J, Rychkov GY, Barritt GJ. Store-operated $\mathrm{Ca}(2+)$ channels and Stromal Interaction Molecule 1 (STIM1) are targets for the actions of bile acids on liver cells. Biochimica et biophysica acta. 2008;1783(5):874-85.

93. Orlando RC, Powell DW, Carney CN. Pathophysiology of acute acid injury in rabbit esophageal epithelium. The Journal of clinical investigation. 1981;68(1):286-93.

94. Kong J, Whelan KA, Laczko D, Dang B, Caro Monroig A, Soroush A, et al. Autophagy levels are elevated in barrett's esophagus and promote cell survival from acid and oxidative stress. Molecular carcinogenesis. 2015.

95. Namkung W, Lee JA, Ahn W, Han W, Kwon SW, Ahn DS, et al. Ca2+ Activates Cystic Fibrosis Transmembrane Conductance Regulator-and Cl--dependent HCO Transport in Pancreatic Duct Cells. Journal of Biological Chemistry. 2003;278(1):200-7.

96. Venglovecz V, Hegyi P, Rakonczay Z, Tiszlavicz L, Nardi A, Grunnet M, et al. Pathophysiological relevance of apical large-conductance $\mathrm{Ca} 2+$-activated potassium channels in pancreatic duct epithelial cells. Gut. 2010:gut. 2010.214213.

97. ZSEMBERY Á, STRAZZABOSCO M, GRAF J. Ca2+-activated $\mathrm{Cl}-$ channels can substitute for CFTR in stimulation of pancreatic duct bicarbonate secretion. The FASEB Journal. 2000;14(14):2345-56.

98. Emmer E, Rood RP, Wesolek JH, Cohen ME, Braithwaite RS, Sharp GW, et al. Role of calcium and calmodulin in the regulation of the rabbit ileal brush-border membrane $\mathrm{Na}+\mathrm{H}+$ antiporter. The Journal of membrane biology. 1989;108(3):207-15.

99. Weinman EJ, Dubinsky WP, Shenolikar S. Reconstitution of cAMP-dependent protein kinase regulated renal Na+-H+ exchanger. The Journal of membrane biology. 1988;101(1):11-8. 
100. Takubo K, Aida J, Naomoto Y, Sawabe M, Arai T, Shiraishi H, et al. Cardiac rather than intestinal-type background in endoscopic resection specimens of minute Barrett adenocarcinoma. Human pathology. 2009;40(1):65-74.

101. Chow CW. Regulation and intracellular localization of the epithelial isoforms of the $\mathrm{Na}+\mathrm{H}+$ exchangers NHE2 and NHE3. Clinical and investigative medicine Medecine clinique et experimentale. 1999;22(5):195-206.

102. Guan Y, Dong J, Tackett L, Meyer JW, Shull GE, Montrose MH. NHE2 is the main apical NHE in mouse colonic crypts but an alternative Na+-dependent acid extrusion mechanism is upregulated in NHE2-null mice. American journal of physiology Gastrointestinal and liver physiology. 2006;291(4):G689-99.

103. Sun AM, Liu Y, Dworkin LD, Tse CM, Donowitz M, Yip KP. Na+/H+ exchanger isoform 2 (NHE2) is expressed in the apical membrane of the medullary thick ascending limb. The Journal of membrane biology. 1997;160(1):85-90.

104. Amaravadi RK. Autophagy-induced tumor dormancy in ovarian cancer. The Journal of clinical investigation. 2008;118(12):3837-40.

105. Amaravadi RK, Yu D, Lum JJ, Bui T, Christophorou MA, Evan GI, et al. Autophagy inhibition enhances therapy-induced apoptosis in a Myc-induced model of lymphoma. The Journal of clinical investigation. 2007;117(2):326-36.

106. Filomeni G, De Zio D, Cecconi F. Oxidative stress and autophagy: the clash between damage and metabolic needs. Cell death and differentiation. 2015;22(3):377-88.

107. Fitzgerald RC, Omary MB, Triadafilopoulos G. Acid modulation of HT29 cell growth and differentiation. An in vitro model for Barrett's esophagus. Journal of cell science. 1997;110 ( Pt 5):663-71.

108. Hartman KG, Bortner JD, Falk GW, Yu J, Martin MG, Rustgi AK, et al. Modeling inflammation and oxidative stress in gastrointestinal disease development using novel organotypic culture systems. Stem cell research \& therapy. 2013;4 Suppl 1:S5.

109. Tatsuta T, Mukaisho K, Sugihara H, Miwa K, Tani T, Hattori T. Expression of Cdx2 in early GRCL of Barrett's esophagus induced in rats by duodenal reflux. Digestive diseases and sciences. 2005;50(3):425-31. 
110. Kumagai H, Mukaisho K, Sugihara H, Bamba M, Miyashita T, Miwa K, et al. Cell kinetic study on histogenesis of Barrett's esophagus using rat reflux model. Scandinavian journal of gastroenterology. 2003;38(7):687-92.

111. Nishijima K, Miwa K, Miyashita T, Kinami S, Ninomiya I, Fushida S, et al. Impact of the biliary diversion procedure on carcinogenesis in Barrett's esophagus surgically induced by duodenoesophageal reflux in rats. Annals of surgery. 2004;240(1):57-67.

112. Chen X, Qin R, Liu B, Ma Y, Su Y, Yang CS, et al. Multilayered epithelium in a rat model and human Barrett's esophagus: similar expression patterns of transcription factors and differentiation markers. BMC gastroenterology. 2008;8:1.

113. Sarosi G, Brown G, Jaiswal K, Feagins LA, Lee E, Crook TW, et al. Bone marrow progenitor cells contribute to esophageal regeneration and metaplasia in a rat model of Barrett's esophagus. Diseases of the esophagus : official journal of the International Society for Diseases of the Esophagus / ISDE. 2008;21(1):43-50.

114. Clark GW, Smyrk TC, Mirvish SS, Anselmino M, Yamashita Y, Hinder RA, et al. Effect of gastroduodenal juice and dietary fat on the development of Barrett's esophagus and esophageal neoplasia: an experimental rat model. Annals of surgical oncology. 1994;1(3):252-61.

115. Hao J, Liu B, Yang CS, Chen X. Gastroesophageal reflux leads to esophageal cancer in a surgical model with mice. BMC gastroenterology. 2009;9:59.

116. Wang DH, Tiwari A, Kim ME, Clemons NJ, Regmi NL, Hodges WA, et al. Hedgehog signaling regulates FOXA2 in esophageal embryogenesis and Barrett's metaplasia. The Journal of clinical investigation. 2014;124(9):3767-80.

117. Duncan MD, Tihan T, Donovan DM, Phung QH, Rowley DL, Harmon JW, et al. Esophagogastric adenocarcinoma in an E1A/E1B transgenic model involves p53 disruption. Journal of gastrointestinal surgery : official journal of the Society for Surgery of the Alimentary Tract. 2000;4(3):290-7.

118. Kong J, Crissey MA, Funakoshi S, Kreindler JL, Lynch JP. Ectopic Cdx2 expression in murine esophagus models an intermediate stage in the emergence of Barrett's esophagus. PloS one. 2011;6(4):e18280.

119. Nakagawa H, Wang TC, Zukerberg L, Odze R, Togawa K, May GH, et al. The targeting of the cyclin D1 oncogene by an Epstein-Barr virus promoter in transgenic mice causes dysplasia in the tongue, esophagus and forestomach. Oncogene. 1997;14(10):1185-90. 
120. Takubo K, Honma N, Aryal G, Sawabe M, Arai T, Tanaka Y, et al. Is there a set of histologic changes that are invariably reflux associated? Arch Pathol Lab Med. 2005;129(2):15963.

121. Katada N, Hinder RA, Smyrk TC, Hiki Y, Kakita A. Duodenoesophageal reflux induces apoptosis in rat esophageal epithelium. Dig Dis Sci. 1999;44(2):301-10. 